\title{
Vascular and Neuronal Protection in the Developing Retina: Potential Therapeutic Targets for Retinopathy of Prematurity
}

\author{
Jessica K. W. Tsang, Jin Liu and Amy C. Y. Lo *(1) \\ Department of Ophthalmology, Li Ka Shing Faculty of Medicine, The University of Hong Kong, \\ Hong Kong, China \\ * Correspondence: amylo@hku.hk; Tel.: +852-2831-5363
}

Received: 12 July 2019; Accepted: 29 August 2019; Published: 3 September 2019

\begin{abstract}
Retinopathy of prematurity (ROP) is a common retinal disease in preterm babies. To prolong the lives of preterm babies, high oxygen is provided to mimic the oxygen level in the intrauterine environment for postnatal organ development. However, hyperoxia-hypoxia induced pathological events occur when babies return to room air, leading to ROP with neuronal degeneration and vascular abnormality that affects retinal functions. With advances in neonatal intensive care, it is no longer uncommon for increased survival of very-low-birth-weight preterm infants, which, therefore, increased the incidence of ROP. ROP is now a major cause of preventable childhood blindness worldwide. Current proven treatment for ROP is limited to invasive retinal ablation, inherently destructive to the retina. The lack of pharmacological treatment for ROP creates a great need for effective and safe therapies in these developing infants. Therefore, it is essential to identify potential therapeutic agents that may have positive ROP outcomes, especially in preserving retinal functions. This review gives an overview of various agents in their efficacy in reducing retinal damages in cell culture tests, animal experiments and clinical studies. New perspectives along the neuroprotective pathways in the developing retina are also reviewed.
\end{abstract}

Keywords: oxygen-induced retinopathy; neovascularization; vascular protection; vascular endothelial growth factor; animal models; supplementary oxygen therapy; neuron; eye

\section{Introduction}

Retinopathy of prematurity (ROP) is a vasoproliferative retinal disease in the preterm babies. It was initially described and named as retrolental fibroplasia in 1942 [1]. In the normal human fetus with a gestational period of 40 weeks, retinal vascular development starts at gestational week 16, proceeding from the center toward the peripheral retina. In the full-term babies, the retina, including the vessels and neuronal cells, is well-developed at birth, but not in preterm infants. As the preterm infant has an immature cardiopulmonary system, it needs to be placed in high supplemental oxygen. This places the development of the retina at risk and results in ROP.

With the advances in neonatal intensive care, it is no longer uncommon for the increased survival of very-low-birth-weight preterm infants, therefore, increasing the incidence of ROP. Indeed, ROP is now a major cause of preventable childhood blindness in developed and developing countries. Latest estimates from the National Eye Institute showed that 1100-1500 infants ( $5 \%$ infants $\leq 1.25 \mathrm{~kg}$ at birth, $<31$ weeks of gestation) develop severe ROP that requires treatment. As these infants grow up, they have a higher incidence of astigmatism, high myopia, and retinal detachment and should be followed routinely afterwards. Unfortunately, recent estimates from the National Eye Institute showed that 400-600 infants ( $2 \%$ infants weighing $\leq 1.25 \mathrm{~kg}$ at birth, $40 \%$ severe ROP infants) become 
legally blind from ROP despite treatment, translating to losing 30,000 life years of vision. The resulting long-term disability, and severely affected quality of life, in ROP patients poses an intense burden on the pediatrics, adolescent and adult healthcare system worldwide. As the population ages, high societal cost over many years is anticipated-making ROP a major public health issue and justifying a need for adequate management.

Current proven treatment for ROP is limited. Invasive retinal ablation is the most commonly used treatment, but it is inherently destructive to the retina. The lack of pharmacological treatment for ROP creates a great need for effective and safe therapies in these developing infants.

Neuroprotection in ROP is one way that may protect not only the retinal neurons, but also the vasculature. In the past years, many therapeutic targets have been developed, and they are targeted to vascular protection in ROP. In this review, we discussed the pathology and animal models of ROP, as well as the recent vascular protective and potential neuroprotective targets in ROP.

\section{Vasculature in the Retina}

\subsection{Normal Development of the Retinal Vasculature}

The survival and appropriate functioning of retinal cells depend on sufficient oxygen supply. Lack of oxygen may lead to vision loss. In the retina, normal visual process demands high energy, most of which are derived from oxidative metabolism coupled to adenosine triphosphate (ATP) synthesis. In the central nervous system, the brain receives $15 \%$ of the cardiac output and consumes around $20 \%$ of the total body oxygen, although it only represents $2 \%$ of the bodyweight [2]. Meanwhile, the consumption of oxygen in each gram of tissue in the retina has been described higher than that of the brain [3], making retina one of the highest oxygen-consuming tissues in the body [4]. Therefore, a well-organized vascular system providing adequate blood supply is important for the retina to maintain its normal function.

The blood supply of the retina is provided by two vascular systems: The retinal vessels for the inner two-thirds of the retina, and the choroidal system for outer one-third of the retina [5]. During development, the inner retinal vascular system undergoes significant changes and reorganizations. At the very beginning, tissues in the inner part of the eye are nourished by the hyaloid vasculature, which is a vitreous arterial network. In this hyaloid vascular system, blood enters through the central hyaloid artery initiating from the optic nerve, runs in hyaloid vessels and then exits through an annular collection vessel in the anterior part of the eye. The hyaloid vasculature is gradually replaced by the retinal vasculature as the development paces on $[5,6]$. The regression of hyaloid vasculature in humans occurs around mid-gestation, and in mouse occurs around birth [7]. At almost the same time as hyaloid vascular system regresses, retinal vasculature begins to emerge from the optic nerve head. This newly formed vascular plexus expands in the nerve fiber layer across the inner surface of the retina. Unlike the hyaloid vasculature, this plexus has both arteries and veins which go in and out of the optic nerve. Later, the primary vascular plexus gives rise to two other networks. Three of these vascular plexuses are parallel and inter-connected, which locates in the nerve fiber layer, inner plexiform layer and outer plexiform layer, respectively. In human beings, the normal retinal vascular development begins at around 16 weeks of gestation and accomplishes around birth. In mouse retina, the primary plexus reaches the periphery of the retina on about postnatal $(\mathrm{P})$ day 8 , and the three retinal vascular plexuses establish on about P21. The direction of vascular formation is from the center to the periphery; thus, vessels at the growing edge are less mature than those in the central areas. It is, therefore, possible to observe different stages of vascular differentiation in a peripheral to the central gradient.

\subsection{Pathogenesis of Retinopathy of Prematurity}

A major cause of blindness in children is ROP, a condition commonly found in preterm babies that are related to abnormal development of retinal blood vessels. Clinically, preterm infants are placed in high supplemental oxygen to facilitate breathing due to their immature cardiopulmonary system. 
The exposure to high oxygen (hyperoxia) during the first ischemic phase inhibits the production and secretion of pro-angiogenic factors, e.g., vascular endothelial growth factor (VEGF) and insulin-like growth factor-1 (IGF-1), while stimulating the formation of reactive oxygen species (ROS) [8,9]. As a result, apoptosis of vascular endothelial cells causes cessation of normal vessel growth and pruning of the existing immature vasculature, which, in turn, leads to retinal avascularity. The retinal response during this phase may also be mediated by hyperoxia-induced free radicals, although their roles remain unclear. Later, when the prematurely born infant acquires adequate cardiopulmonary functions, oxygen supplementation is discontinued, and the infant is returned to stay in normal room air. Now, relative retinal hypoxia occurs due to high oxygen demand from the maturing neural components. During this second vaso-proliferative phase, a compensatory release of pro-angiogenic factors is triggered. The expressions of VEGF, IGF-1 and erythropoietin (Epo) are increased, while hypoxia also facilitates the accumulation of hypoxia-inducible factor (HIF) [9]. There are now upregulated vessel growth and neovascularization (Table 1). These fragile neovascular tufts will, in turn, lead to intravitreal hemorrhages, retinal detachment and subsequent vision loss. Although poorly studied, the fluctuations in oxygen tension also predispose retinal neurons to degeneration (Figure 1). In fact, retinal dysfunction has been reported in infants and children with a history of ROP.

The etiology of ROP appears to be multifactorial. The severity of ROP is inversely proportional to gestational age, which is the greatest risk factor. A multi-centered national study, Supplemental Therapeutic Oxygen for Prethreshold Retinopathy of Prematurity (STOP-ROP) found that oxygen (96-99\% saturation) does not cause additional progression of pre-threshold ROP [10]. However, there was absolutely no data to suggest that high oxygen level is safe for the early immature eye in the preterm infants that have not yet established ROP. On the other hand, it has been shown that the progression of ROP is closely related to the supplementary oxygen therapy that provided for the preterm babies after birth [11-13]. The lower oxygen concentration in the therapy has a beneficial effect on ROP development and can lower the severity of ROP [14]. However, if the preterm infant requires supplemental oxygen due to cardio-pulmonary reasons, withholding oxygen for fear of causing ROP is not recommended. Therefore, an understanding of tissue hyperoxia/hypoxia swing, as well as free radical and pro-angiogenic factor productions is integral to the prevention and treatment for ROP.

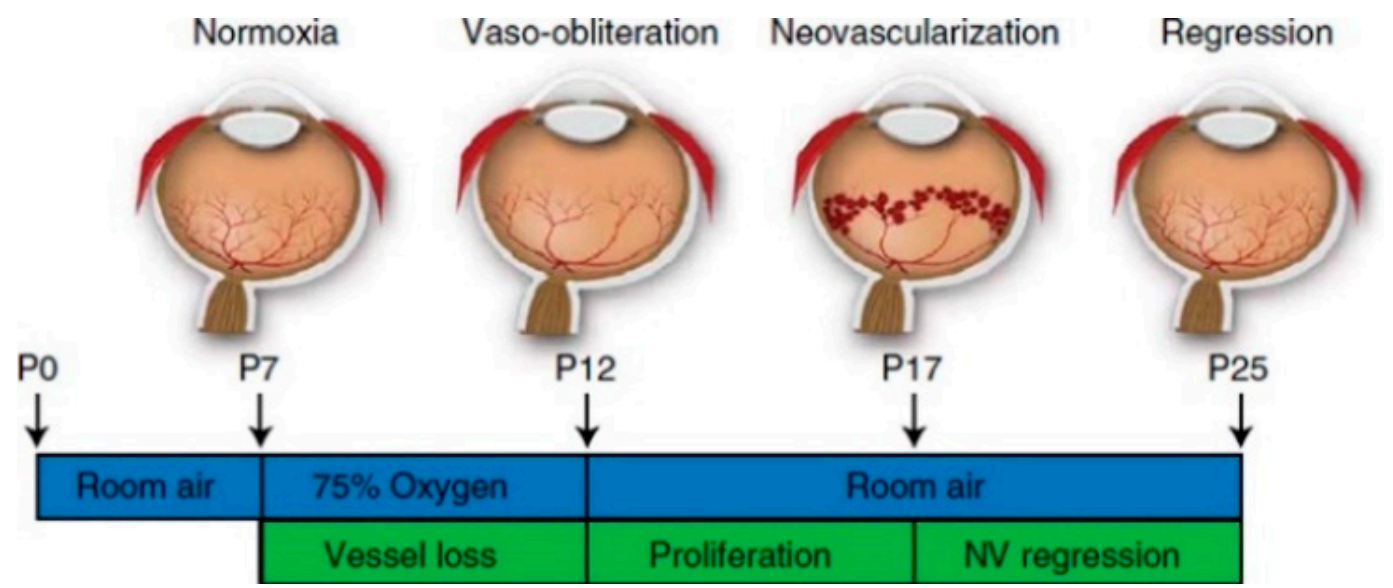

Figure 1. Schematic diagram of mouse oxygen-induced retinopathy (OIR) model [15]. The nursing mother and their pups were exposed to a $75 \%$ hyperoxia environment, which simulates the supplementary oxygen therapy in human. It results in vessel loss and presents features similar to those in phase 1 of human retinopathy of prematurity (ROP) development. Pups return to room air after P12. Hypoxia-induced neovascularization starts from P14 and maximizes at P17. Neovascular formation after hyperoxia in the mouse OIR model mimics phase 2 of human ROP development. 
Table 1. Vascular protective agents in the role of ROP development.

\begin{tabular}{|c|c|c|c|c|c|c|c|c|}
\hline $\begin{array}{l}\text { Pathogenic } \\
\text { Agents in ROP }\end{array}$ & $\begin{array}{l}\text { Phase } 1 \text { in ROP } \\
\text { Development }\end{array}$ & $\begin{array}{l}\text { Phase } 2 \text { in ROP } \\
\text { Development }\end{array}$ & $\begin{array}{l}\text { Relevant Vascular } \\
\text { Protective Agents in } \\
\text { ROP Development } \\
\text { (Phase of ROP) }\end{array}$ & Intervention & Animal Model & Beneficial Effect & Adverse Effect & Reference \\
\hline \multirow[t]{8}{*}{ VEGF } & $\downarrow$ & $\uparrow$ & VEGF (Phase 1) & $\begin{array}{l}\text { Intraocular } \\
\text { injection }\end{array}$ & Rat OIR model & $\begin{array}{l}\text { - Prevention of apoptosis of } \\
\text { vascular endothelial cells } \\
\text { - } \quad \text { Reduction in avascular area }\end{array}$ & l & [16] \\
\hline & & & $\begin{array}{l}\text { Bevacizumab } \\
\text { (Phase 2) }\end{array}$ & $\begin{array}{l}\text { Intravitreal } \\
\text { injection }\end{array}$ & (Clinical study) & \multirow{3}{*}{$\begin{array}{l}\text { - Reduction of the avascular area } \\
\text { and continuing vessels growth }\end{array}$} & $\begin{array}{ll}\text { - } & \text { Reduced systemic VEGF level } \\
\text { after injection } \\
\text { - } & \text { Influenced the } \\
\text { long-term neurodevelopment }\end{array}$ & {$[17-23]$} \\
\hline & & & $\begin{array}{l}\text { Ranibizumab } \\
\text { (Phase 2) }\end{array}$ & $\begin{array}{l}\text { Intravitreal } \\
\text { injection }\end{array}$ & (Clinical study) & & l & {$[19,24,25]$} \\
\hline & & & Aflibercept (Phase 2) & $\begin{array}{l}\text { Intravitreal } \\
\text { injection }\end{array}$ & $\begin{array}{l}\text { Mouse OIR } \\
\text { model }\end{array}$ & & I & [26] \\
\hline & & & $\begin{array}{l}\text { VEGFA shRNA } \\
\text { (Phase 2) }\end{array}$ & $\begin{array}{l}\text { Subretinal } \\
\text { injection }\end{array}$ & Rat OIR model & $\begin{array}{l}\text { - } \quad \text { Reduced VEGF expression } \\
\text { - Inhibited neovascularization in } \\
\text { short- and long-term studies }\end{array}$ & l & [27] \\
\hline & & & Anti-KDR (Phase 2) & $\begin{array}{l}\text { Surgical } \\
\text { implantation }\end{array}$ & Dog OIR model & - Suppressed neovascularization & l & [28] \\
\hline & & & SRPIN340 (Phase 2) & $\begin{array}{l}\text { Intraocular } \\
\text { injection }\end{array}$ & Rat OIR model & - $\quad$ Reduced VEGF expression & l & [29] \\
\hline & & & Rapamycin (Phase 2) & $\begin{array}{l}\text { Subcutaneous } \\
\text { injection }\end{array}$ & $\begin{array}{l}\text { Mouse OIR } \\
\text { model }\end{array}$ & - Reduced neovascularization & l & {$[30]$} \\
\hline IGF-1 & $\downarrow$ & $\uparrow$ & rhIGF-1 (Phase 1) & $\begin{array}{l}\text { Intraperitoneal } \\
\text { injection }\end{array}$ & $\begin{array}{l}\text { Mouse OIR } \\
\text { model }\end{array}$ & $\begin{array}{ll}\text { - } & \text { Higher score in } \\
\text { maturation assessments } \\
\text { - } & \text { Reduced neovascularization }\end{array}$ & l & {$[31]$} \\
\hline
\end{tabular}


Table 1. Cont

\begin{tabular}{|c|c|c|c|c|c|c|c|c|}
\hline $\begin{array}{l}\text { Pathogenic } \\
\text { Agents in ROP }\end{array}$ & $\begin{array}{l}\text { Phase } 1 \text { in ROP } \\
\text { Development }\end{array}$ & $\begin{array}{l}\text { Phase } 2 \text { in ROP } \\
\text { Development }\end{array}$ & $\begin{array}{l}\text { Relevant Vascular } \\
\text { Protective Agents in } \\
\text { ROP Development } \\
\text { (Phase of ROP) }\end{array}$ & Intervention & Animal Model & Beneficial Effect & Adverse Effect & Reference \\
\hline & & & $\begin{array}{l}\text { IGFBP3 } \\
\text { (Phase } 1 \text { and 2) }\end{array}$ & $\begin{array}{l}\text { Knockout } \\
\text { mouse }\end{array}$ & $\begin{array}{l}\text { Mouse OIR } \\
\text { model }\end{array}$ & $\begin{array}{ll}\text { - } & \text { Reduced neuronal } \\
\text { cell apoptosis } \\
\text { - } & \text { Larger retinal avascular area }\end{array}$ & l & {$[32,33]$} \\
\hline & & & Jb3 (Phase 2) & $\begin{array}{l}\text { Subcutaneous } \\
\text { injection }\end{array}$ & $\begin{array}{l}\text { Mouse OIR } \\
\text { model }\end{array}$ & $\begin{array}{l}\text { - Less neovascular } \\
\text { tufts formation }\end{array}$ & I & {$[34]$} \\
\hline Epo & $\downarrow$ & $\uparrow$ & l & I & l & $\cdot 1$ & l & l \\
\hline \multirow[t]{3}{*}{ HIF-1 } & $\downarrow$ & $\uparrow$ & DMOG (Phase 1) & $\begin{array}{l}\text { Intraperitoneal } \\
\text { injection }\end{array}$ & $\begin{array}{l}\text { Mouse OIR } \\
\text { model }\end{array}$ & \multirow{2}{*}{$\begin{array}{l}\text { Prevented vessel loss and } \\
\text { vessel tufts formation }\end{array}$} & 1 & [35] \\
\hline & & & PHD2 (Phase 1 and 2) & $\begin{array}{l}\text { Knockout } \\
\text { mouse }\end{array}$ & $\begin{array}{l}\text { Mouse OIR } \\
\text { model }\end{array}$ & & I & [36] \\
\hline & & & $\begin{array}{l}\text { RTP801 } \\
\text { (Phase } 1 \text { and 2) }\end{array}$ & $\begin{array}{l}\text { Knockout } \\
\text { mouse }\end{array}$ & $\begin{array}{l}\text { Mouse OIR } \\
\text { model }\end{array}$ & $\begin{array}{ll}\text { - Induced transcription of HIF-1 } \\
\text { in phase } 2 \\
\text { - } \\
\text { Reduced neovascular tufts and } \\
\text { lower apoptosis }\end{array}$ & l & [37] \\
\hline \multirow[t]{3}{*}{$\mathrm{NO}$} & $\downarrow$ & $\uparrow$ & L-NA (Phase 2) & $\begin{array}{l}\text { Intraperitoneal } \\
\text { injection }\end{array}$ & Rat OIR model & \multirow{3}{*}{$\begin{array}{l}\text { - Reduced avascular zone and } \\
\text { neovascular tufts }\end{array}$} & I & [38] \\
\hline & & & L-NNA (Phase 2) & $\begin{array}{l}\text { Intraperitoneal } \\
\text { injection }\end{array}$ & $\begin{array}{l}\text { Mouse OIR } \\
\text { model }\end{array}$ & & I & [39] \\
\hline & & & AG (Phase 2) & $\begin{array}{l}\text { Intravitreal } \\
\text { injection }\end{array}$ & $\begin{array}{l}\text { Mouse OIR } \\
\text { model }\end{array}$ & & I & {$[40]$} \\
\hline Adenosine & $\downarrow$ & $\uparrow$ & 1 & 1 & 1 & 1 & 1 & 1 \\
\hline \multirow[t]{2}{*}{$\beta$-AR } & $?$ & $\uparrow$ & \multirow{2}{*}{ Propranolol (Phase 2) } & $\begin{array}{l}\text { Subcutaneous } \\
\text { injection }\end{array}$ & $\begin{array}{l}\text { Mouse OIR } \\
\text { model }\end{array}$ & \multirow{2}{*}{$\begin{array}{ll}- & \text { Reduced neovascularization } \\
- & \text { Reduced VEGF expression }\end{array}$} & 1 & [41] \\
\hline & & & & $\begin{array}{l}\text { Topical } \\
\text { administration }\end{array}$ & $\begin{array}{l}\text { Mouse OIR } \\
\text { model }\end{array}$ & & I & [42] \\
\hline
\end{tabular}


Table 1. Cont.

\begin{tabular}{|c|c|c|c|c|c|c|c|c|}
\hline $\begin{array}{l}\text { Pathogenic } \\
\text { Agents in ROP }\end{array}$ & $\begin{array}{l}\text { Phase } 1 \text { in ROP } \\
\text { Development }\end{array}$ & $\begin{array}{l}\text { Phase } 2 \text { in ROP } \\
\text { Development }\end{array}$ & $\begin{array}{l}\text { Relevant Vascular } \\
\text { Protective Agents in } \\
\text { ROP Development } \\
\text { (Phase of ROP) }\end{array}$ & Intervention & Animal Model & Beneficial Effect & Adverse Effect & Reference \\
\hline & & & Atenolol (Phase 2) & \multirow{3}{*}{$\begin{array}{l}\text { Subcutaneous } \\
\text { injection }\end{array}$} & \multirow{3}{*}{$\begin{array}{l}\text { Mouse OIR } \\
\text { model }\end{array}$} & \multirow{3}{*}{$\begin{array}{l}\text { - Reduced avascular zone and } \\
\text { neovascular tufts }\end{array}$} & 1 & \multirow{3}{*}[43]{} \\
\hline & & & ICI 118,551 (Phase 2) & & & & 1 & \\
\hline & & & SR59230A (Phase 2) & & & & 1 & \\
\hline \multirow[t]{10}{*}{$\begin{array}{l}\text { Other } \\
\text { angiogenic } \\
\text { agents }\end{array}$} & $?$ & $\uparrow$ & $\begin{array}{l}\text { Dexamethasone } \\
\text { (Phase 2) }\end{array}$ & $\begin{array}{l}\text { Subcutaneous } \\
\text { injection }\end{array}$ & $\begin{array}{l}\text { Mouse OIR } \\
\text { model }\end{array}$ & - Suppressed & - Steroid has a higher risk of & {$[44]$} \\
\hline & & & $\begin{array}{l}\text { Anecortave acetate } \\
\text { (Phase 2) }\end{array}$ & $\begin{array}{l}\text { Intravitreal } \\
\text { injection }\end{array}$ & Rat OIR model & r tormation & sepsis development & [45] \\
\hline & & & Degulin (Phase 2) & $\begin{array}{l}\text { Intravitreal } \\
\text { injection }\end{array}$ & $\begin{array}{l}\text { Mouse OIR } \\
\text { model }\end{array}$ & \multirow{3}{*}{ - Regulated HIF- $1 \alpha$ suppression } & I & [46] \\
\hline & & & YC-1 (Phase 2) & $\begin{array}{l}\text { Intravitreal } \\
\text { injection }\end{array}$ & $\begin{array}{l}\text { Mouse OIR } \\
\text { model }\end{array}$ & & l & [47] \\
\hline & & & $\beta$-lapachone (Phase 2) & $\begin{array}{l}\text { Intravitreal } \\
\text { injection }\end{array}$ & $\begin{array}{l}\text { Mouse OIR } \\
\text { model }\end{array}$ & & I & [48] \\
\hline & & & 16K HPRL (Phase 2) & $\begin{array}{l}\text { Intravitreal } \\
\text { injection }\end{array}$ & $\begin{array}{l}\text { Mouse OIR } \\
\text { model }\end{array}$ & \multirow{2}{*}{$\begin{array}{l}\text { - Mediated endothelial } \\
\text { cell proliferation }\end{array}$} & I & [49] \\
\hline & & & 12-LOX (Phase 2) & $\begin{array}{l}\text { Intraperitoneal } \\
\text { injection }\end{array}$ & $\begin{array}{l}\text { Mouse OIR } \\
\text { model }\end{array}$ & & I & {$[50]$} \\
\hline & & & TMP (Phase 2) & $\begin{array}{l}\text { Intraperitoneal } \\
\text { injection }\end{array}$ & $\begin{array}{l}\text { Mouse OIR } \\
\text { model }\end{array}$ & \multirow{3}{*}{$\begin{array}{l}\text { - Prevented } \\
\text { neovascular formation }\end{array}$} & I & {$[51]$} \\
\hline & & & K5 (Phase 2) & $\begin{array}{l}\text { Intravitreal } \\
\text { injection }\end{array}$ & Rat OIR model & & I & {$[52]$} \\
\hline & & & $\begin{array}{l}\text { MEF2C } \\
\text { (Phase } 1 \text { and 2) }\end{array}$ & $\begin{array}{l}\text { Knockout } \\
\text { mouse }\end{array}$ & $\begin{array}{l}\text { Mouse OIR } \\
\text { model }\end{array}$ & & I & {$[53]$} \\
\hline
\end{tabular}

Abbreviations: Short hairpin RNA linked VEGF (VEGFA shRNA), kinase insert domain-containing receptors (KDR), recombinant human IGF-1 (rhIGF-1), IGF binding protein (IGFBP), dimethyloxalylglycine (DMOG), prolyl hydroxylase (PHD), nitric oxide (NO), N-nitro-l-arginine (L-NA), N G-nitro-l-arginine (L-NNA), aminoguanidine (AG), N-terminal fragment of human prolactin (16K HPRL), 12-lipoxygenase (12-LOX), tetramethylpyrazine (TMP), plasminogen kringle (K5), myocyte enhancer factor $2 \mathrm{C}(\mathrm{MEF} 2 \mathrm{C})$. $\uparrow=$ upregulated; $\downarrow=$ downregulated; ? = unknown. 


\subsubsection{Vascular Endothelial Growth Factor (VEGF)}

VEGF plays for a key role in vascular development and angiogenesis [54,55]. There are three predominant VEGF isoforms in human (VEGF121, VEGF165 and VEGF189). There are two receptors common for all isoforms, which include fms-related tyrosine kinase 1 (FLT-1, also called VEGFR-1), and kinase insert domain-containing receptors (KDR, also known as FLK-1 or VEGFR-2). Meanwhile, heparin sulphate proteoglyvans (HSPGs), neurophilin 1 (NRP-1) and neurophilin 2 (NRP-2) are the receptors that only recognize the VEGF165 isoform [56]. Under hypoxia, the expression of flt-1 gene is upregulated that leads to a higher binding efficiency between HIF-1 $\alpha$ and VEGF promotor [57,58]. Unlike FLT-1, KDR is not induced by hypoxia, but it is important for normal early vascular development [59-62]. The main function of KDR is cell proliferation, differentiation, migration and maturation. There are several known VEGF sources in the human retina, including retinal pigmented epithelial cells, endothelial cells, astrocytes, Müller cells and other ocular tissues [63]. The retinal angiogenic changes under hypoxia are stimulated by the astrocytes release VEGF for vascular development toward the periphery [64], while the Müller cells release VEGF for vessel growth in the deep vascular plexus [65,66]. VEGF is one of the most important elements for ROP progression when it is under hypoxia condition.

\subsubsection{Insulin-Like Growth Factor-1 (IGF-1)}

IGF-1 is a growth factor that is received maternally through the amniotic fluid and placenta during fetal development. IGF-1 plays a critical role in both normal retinal development and pathological ROP progression [67]. Despite a normal VEGF expression, IGF-deficient mice displayed an abnormal vasculature and slower vascular growth rate, indicating that IGF-1 is a key growth factor for vascular development in the early stage [67]. In the first stage of ROP, hyperoxia suppresses the expression of VEGF and IGF-1, whose levels control the survival of endothelial cells by the downstream Akt signaling $[67,68]$. Although a normal concentration of VEGF and IGF-1 supports the survival of endothelial cells, IGF-1 promotes apoptosis under hyperoxia in the first stage of ROP. In turn, this reduces vessel growth and give rises to an avascular retina.

Under hypoxia, the concentration of IGF-1 is gradually increased. IGF-1 can regulate the level of VEGF through different signaling pathways (such as p44/42 NARK pathway and P13K/Akt pathway) and results in neovascularization. Under various oxygen levels, IGF-1 has a different expression level and in combination with VEGF and HIF-1 can stimulate abnormal neovascular growth. A significantly high IGF-1 level inhibits the apoptosis of endothelial cells and promotes neovascularization by accumulating VEGF in the vitreous [68], resulting in ROP.

\subsubsection{Erythropoietin (Epo)}

Epo is secreted from the fetal liver and adult kidney. This glycoprotein binds to the homodimer Epo receptors (EpoR) for inducing erythropoiesis, or binds to the heterodimer receptor, which consists of EpoR and common $\beta$ receptor $(C \beta-R)$, for another function. Epo has a beneficial effect on the experimental models of stroke and light-induced retinal degeneration [69]. Meanwhile, it also works as a mitogenic factor for endothelial cells of brain capillaries. Epo production can be stimulated by hypoxia, thus, induces angiogenesis. VEGF and Epo have a direct relationship, and both are stimulated by HIF-1 $\alpha$. Under hypoxia, not only the expression of VEGF is upregulated, but also Epo [70]. VEGF and Epo have similar functions in vascular proliferation. In the Epo-deficiency animal model, the vascular loss and neovascularization formation were both reduced in the retina that, in turn, decreased the disease damage in oxygen-induced retinopathy (OIR) [71]. In addition, the level of Epo is directly correlated with the level of VEGF and plays a similar role in endothelial cell proliferation in the second stage of ROP. 


\subsubsection{Hypoxia-Inducible Factor-1 (HIF-1)}

HIF-1 contains $\alpha$ and $\beta$ subunits. This heterodimer plays a critical part in body regulation under hypoxia [72]. HIF- $1 \alpha$ is a short-lived nuclear protein. Under normal condition, HIF- $1 \alpha$ is hydroxylated and degraded by prolyl hydroxylase (PHD). However, in a low oxygen environment, HIF-1 $\alpha$ is not hydroxylated, and PHD is no longer efficient, thereby stimulating the accumulation of HIF-1 $\alpha$ inside the nucleus. The combination of $\alpha$ and $\beta$ subunits are then facilitated, which, in turn, binds to the hypoxia response element (HRE) in the VEGF promotor region. Sufficient accumulation of HIF-1 $\alpha$ under hypoxia induced VEGF production [56,72]. Therefore, there is a direct relationship between hypoxia, HIF-1 $\alpha$ and VEGF expression.

\subsubsection{Nitric Oxide (NO)}

NO is the core element for the signaling process that is synthesized by NOS (nitric oxide synthetase). Two isoforms of NOS work in different roles by different manners, which include the constitutive (cNOS) and inducible (iNOS). The cNOS, such as endothelial (eNOS) and neuronal NOS (nNOS), synthesizes $\mathrm{NO}$ when the secretion of calcium is upregulated. Unlike cNOS, iNOS is a calcium-independent enzyme and is only found in specific tissues [56]. The regulation of NO depends on the stimulation or suppression of the specific NOS.

The change in oxygen concentration affects the expression of eNOS, as well as NO concentration. $\mathrm{NO}$ level is lowered when the expression of eNOS is reduced during hyperoxia. It promotes the inhibition of proliferation and formation of avascular retina [73,74]. Under hypoxia, eNOS expression is stimulated, which, in turn, increases the NO concentration and induces angiogenesis [75]. The NO production during the hyperoxia-hypoxia induction is correlated with the severity of ROP.

\subsubsection{Adenosine}

Adenosine is an endogenous nucleotide and acts as a neuromodulator. In the retina, it is generated during AMP hydrolysis by $5^{\prime}$ nucleotidase $\left(5^{\prime} \mathrm{N}\right)$ in the Müller cells. Adenosine release is mainly caused by stress, tissue activity, or hypoxia. The level of adenosine is also changed under different oxygen level as the activity of $5^{\prime} \mathrm{N}$ is suppressed under hyperoxia and is induced under hypoxia. Adenosine regulates different cell functions by activating different adenosine receptors which consist of adenosine 1 receptor $\left(A_{1} R\right)$, adenosine $2 A$ receptor $\left(A_{2 A} R\right)$, adenosine $2 B$ receptor $\left(A_{2 B} R\right)$ and adenosine 3 receptor $\left(A_{3} R\right)$ [76]. $A_{2 A} R$ is closely related with neurodegeneration [77] and demonstrated a positive effect after blockage of $A_{2 A} R$ in neurodegenerative models, such as Parkinson disease (PD) [78,79], Alzheimer disease (AD) [80] and ischemia [81]. This receptor interferes with microglial-mediated inflammation that, in turn, induce neuronal damage by stimulating NO production from the microglia-derived mediators [82]. Therefore, more adenosines are released and subsequently stimulates neuronal death and vascular endothelial cells proliferation [83-85] by microglial-mediated inflammatory responses in the second stage of ROP. Recently, several studies demonstrated the association between early microglial activation and retinal ganglion cell death in a glaucoma model and indicated that these two events were initiated simultaneously and contributed to the progression of neurodegenerative diseases $[79,82,86,87]$. Therefore, there is a direct relationship between $\mathrm{A}_{2 \mathrm{~A}} \mathrm{R}$ stimulation, microglial activation and apoptosis in retinal ganglion cells in the onset of neurodegenerative diseases.

\subsection{7. $\beta$-Adrenergic Receptor ( $\beta$-AR)}

Adrenergic receptors (AR) play a role in an internal regulatory manner that is mediated by adrenaline and noradrenalin. Two types of adrenergic receptors, $\alpha$-and $\beta$-AR, tend to have a systemic response after binding with its agonists. $\alpha$-AR promotes the action of muscle contraction, and insulin suppression, as well as induces platelet aggregation. Unlike, $\alpha$-AR, $\beta$-AR has totally opposite effects, such as muscle relaxation and induction of the secretion of insulin, VEGF and renin [72]. The concentration of $\beta$-AR is higher during aging and hypoxia [88]. Cell proliferation is also induced by 
the stimulation of $\beta$-AR under hypoxia [89]. Recent studies indicated that $\beta$-AR was overexpressed in the vascular endothelial cells [90] and regulated the neovascular formation. This evidence suggests that $\beta$-AR has a role in abnormal neovascular formation and responses to ischemia and hypoxic condition.

\section{Animal Models for ROP-Oxygen-Induced Retinopathy (OIR)}

It is an ethical problem for drug testing in human preterm infants; therefore, an animal model is desirable for studying the mechanism and possible therapy for ROP. OIR is an in vivo method for mimicking human ROP. The animals that are used in OIR are full-term neonates with an immature retinal development at birth so that further retinal development under various experimental conditions can be monitored. Although animal models are one way to investigate ROP, they cannot fully simulate the situation in human. Human preterm babies usually have complications after birth, such as bronchopulmonary dysplasia, sepsis and necrotizing enterocolitis, which are seldom observed in the full-term newborn animals. Among the various animal models for ROP, the duration and oxygen level provided for inducing avascular zone and neovascularization are different in different animals. Among these, mouse and rat OIR models are the most common animal models to study ROP.

A mouse OIR model was generated in the 1990s by Smith and colleagues for studying the pathogenesis of ROP [91,92]. This OIR model is one of the commonest models in ROP study. Mouse neonates and their lactating mother are exposed to high oxygen (75\%) environment from P7 to 12 , and then returned to room air to induce OIR. After hyperoxia-hypoxia induction, a large central avascular zone is seen on P12, and a peak neovascularization is observed on P17 (Figure 1). There are a number of advantages that the mouse OIR model can offer. Firstly, it is convenient to use a stable oxygen level for five days. Secondly, it is easy to obtain transgenic mice with OIR for investigating the mechanism of ROP. However, mouse OIR model does not completely represent all the pathologies seen in human ROP as mentioned above. Besides the various complications seen in human preterm babies, newborn mice have higher arterial oxygen after OIR when compared with human infants. In addition, the avascular zone is induced in the central retina in mice, but a peripheral avascular retina is actually observed in human [34]. Although there are some limitations in the mouse OIR model, the mouse is an animal that is easy to handle for further studies the pathogenesis of ROP.

Another OIR model that is commonly used is the rat model. Rat OIR model was designed by Penn in 1993 [93]. Unlike the mouse OIR model, a hyperoxia-hypoxia cycle by fluctuating oxygen level is utilized for inducing avascularization and neovascularization in rat. The oxygen-controlled environment is changed from $50 \%$ to $10 \%$ oxygen for 14 days after birth (from P0 to P14) and is changed every $24 \mathrm{~h}$. One advantage of this rat model is its closeness to human ROP. Both rat and human have similar arterial oxygen. In addition, the appearance of OIR induced retinal vascular development is similar to type 1 severe ROP. As in human, rats have a peripheral avascular retina after OIR. However, the availability and usage of transgenic rats are limited. The molecular mechanism or pharmacologic pathway is also more difficult to analyze using the rat OIR model.

\section{Vascular Protection in the ROP}

Over the past 80 years, many ROP studies have been concentrated on vascular changes. The measurements of avascular and neovascular areas are the comparative method for identifying the protective roles of agents. Many therapeutic studies in ROP would conclude a vascular protective effect when a reduction of avascularization and neovascularization is observed, but there is very limited data on neuronal responses after treatment.

Many components are responsible for the internal regulation of retinal vessel development under hyperoxia or hypoxia. Hypoxia-induced oxidative stress is the common product of imbalance between prooxidants and antioxidants. Some oxygen-sensitive agents, such as VEGF, IGF, and HIF- $1 \alpha$, have pathological roles in ROP progression; yet, they might have a beneficial effect on vascular changes if they are inhibited or induced during ROP development (Figures 2 and 3). 


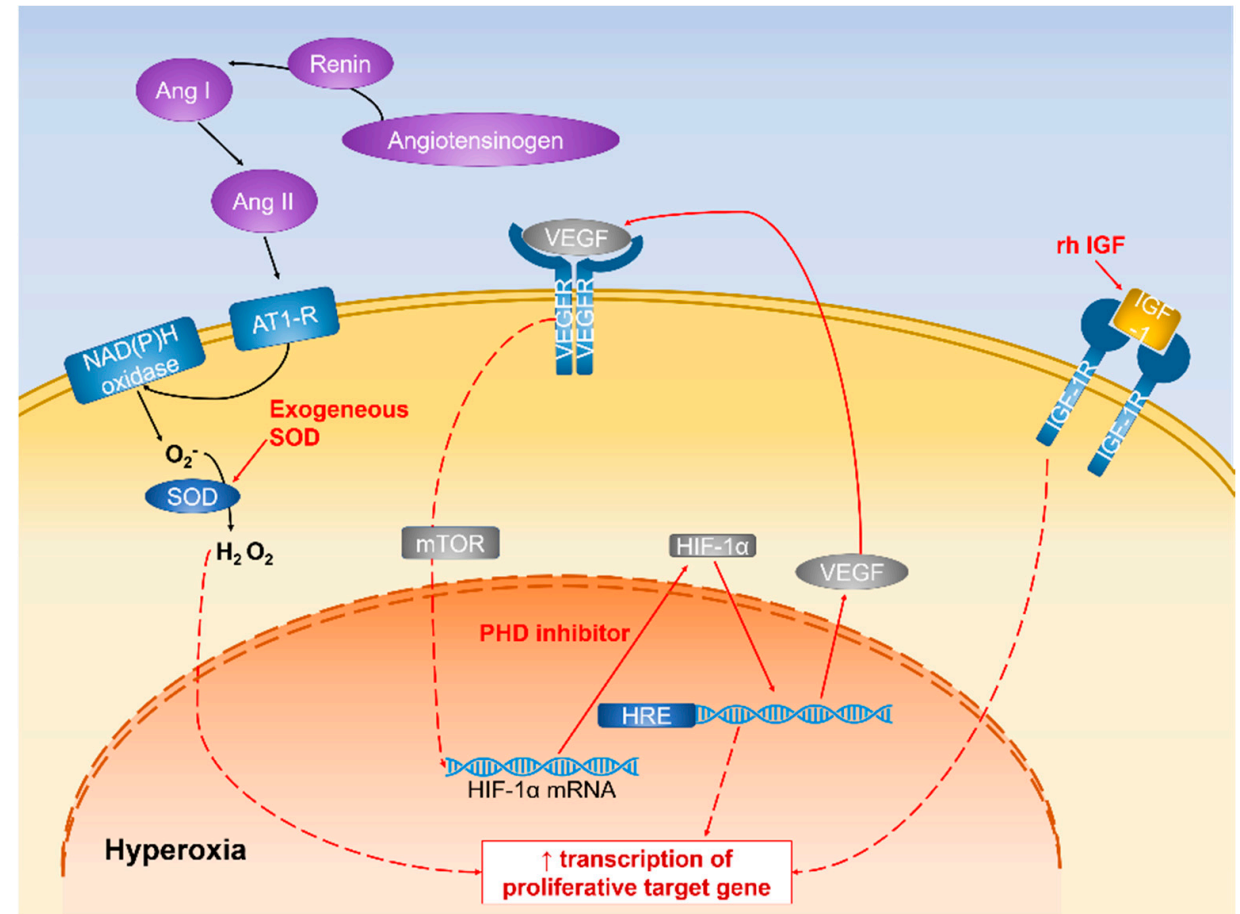

Figure 2. Schematic diagram representing the mechanism of vascular changes in hyperoxic condition. Pathways that confer vascular protection are highlighted in red.

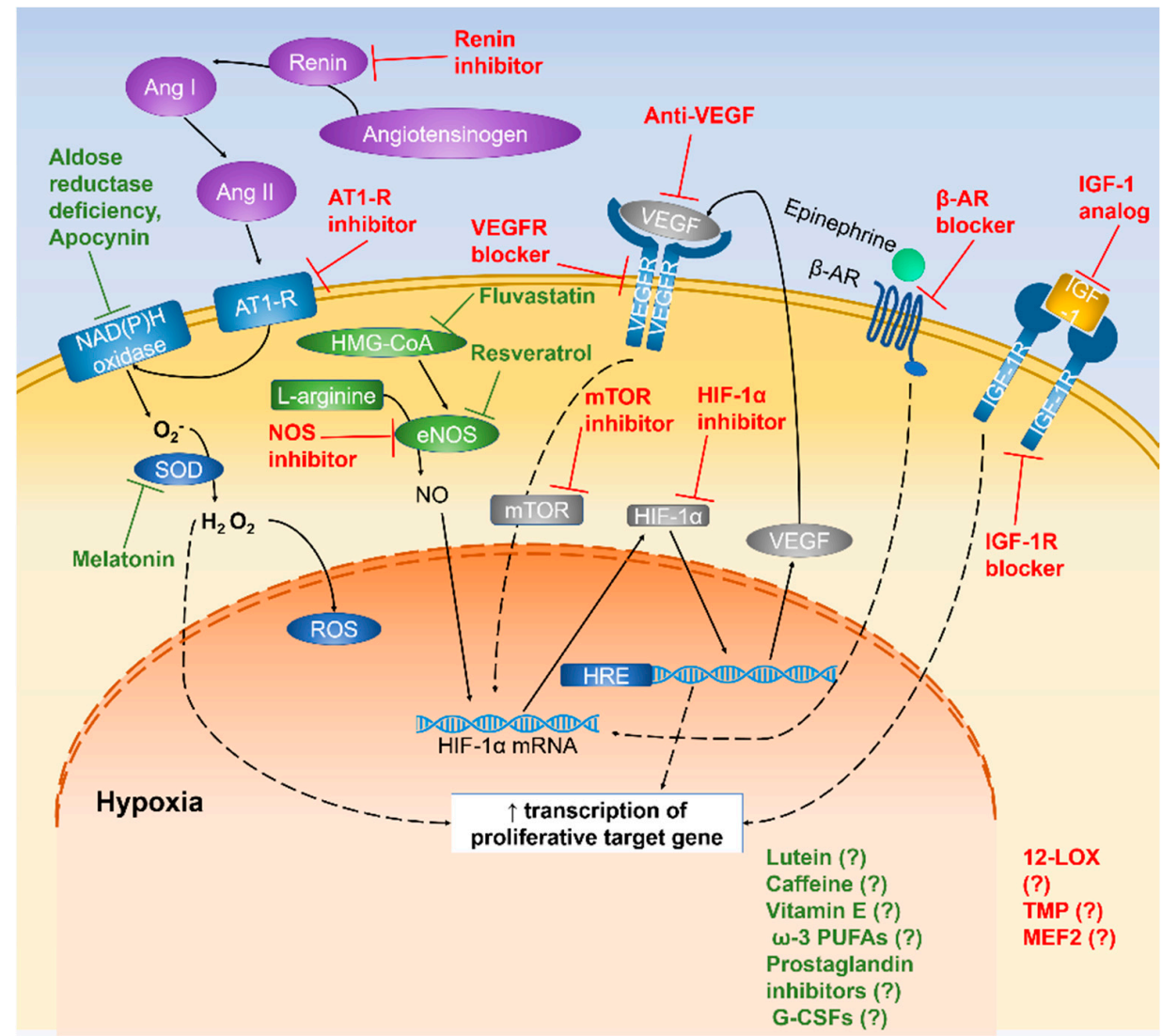

Figure 3. Schematic diagram representing the mechanism of vascular changes in hypoxic condition. Pathways that confer vascular protection are highlighted in red and neuroprotective pathways are highlighted in green. 


\subsection{Growth Factors}

\subsubsection{Anti-VEGF}

VEGF level plays a pathological role in both phase 1 and 2 of ROP. The therapeutic role of VEGF was firstly described in 1995 [53]. VEGF was intraocularly injected during hyperoxia, and this prevented the apoptosis of vascular endothelial cells, resulting in the reduction of avascular area in the rat OIR model. As vessel regression was indicated when there was increased VEGF concentration during hyperoxia, anti-VEGF was then suggested as a potential agent for vascular protection. In anti-VEGF therapy, antibodies attach to VEGF, thus, reducing its own binding to its receptors and the following angiogenic effects. Currently, bevacizumab (Avastin), ranibizumab (Lucentis) and aflibercept (Eylea) are three types of anti-VEGF agents for ROP patients [54,55,59-61]. They have different designs for prolonging the efficiency and eliminating inflammatory responses. Recent animal studies and clinical trials for these three drugs displayed a beneficial effect on intravitreal injection of anti-VEGF in reducing neovascular area and continuing vessels growth toward the peripheral retina after treatment $[54,61,63]$. However, there might be general effects despite a drop in systemic VEGF level after injection $[55,56]$. As the blood-retinal barrier (BRB) is broken down during hypoxia, the injected anti-VEGF agents can enter the vascular system, and in turn, bind to the circulating VEGF. The sudden reduction in VEGF level may indicate a long-term effect of neurodevelopment [59,60]. Although there may be an unknown lifelong effect resulted from an anti-VEGF injection, it is the only efficient treatment for eliminating neovascularization growth in the severe ROP infants now.

Besides these three well-established drugs, other VEGF-related inhibitory agents have been proposed. Short hairpin RNA linked VEGF (VEGFA shRNA), anti-KDR antibody, SRPIN340 and rapamycin were investigated in the suppression of neovascular development. Gene silencing of VEGF could significantly reduce VEGF expression in rat OIR model using VEGFA shRNA injection and also inhibit neovascularization in both short-term and long-term studies [64]. Blockage of the VEGF receptor is another direct way to suppress VEGF activities. KDR is one of the VEGF receptors in human. Anti-KDR did not affect normal vascular development, but suppressed neovascularization in the OIR-treated group [65]. Moreover, SRPIN340 and rapamycin were proposed for indirectly reducing VEGF expression. SRPIN340 is the inhibitor of serine arginine protein kinase 1 (SRPK1), which plays a role of phosphorylation of SRSF1 and VEGF165 splicing. The phosphorylated serine-rich splicing factor-1 (SRSF1) translocates to the nucleus and induces alternative splicing, resulting in upregulation of VEGF. The injection of SRPIN340 significantly decreased VEGF concentration in OIR-treated rats [66]. Rapamycin has an anti-angiogenic effect by inhibiting the mammalian target of rapamycin (mTOR), which is the VEGF induced pathway. The neovascular area was reduced after rapamycin-treated in OIR mice [67]. Through either a direct or an indirect way of VEGF inhibition, the anti-VEGF agents could successfully eliminate the activity of hypoxia-induced upregulation of VEGF.

\subsubsection{IGF-Binding Protein (IGFBP)}

Based on the understanding of IGF expression in ROP progression, the therapeutic targets are either increasing IGF level in phase 1 or reducing IGF concentration in phase 2. IGF concentration was enhanced by injection of recombinant human IGF-1 (rhIGF-1) before hyperoxia [68]. The mouse pups that received rhIGF-1 were heavier and had a higher score in maturation assessments, including the appearance of black skin color and eye opening. They also had lower neovascularization comparing with placebo. For reducing IGF level in the hypoxia phase, IGFBP3 and Jb3 were investigated. In the normal situation, free IGF-1 tends to bind with the IGF-1 receptor on the cell surface and induce angiogenesis. If there is more IGFBP3 in the extracellular fluid, IGFBP3 will bind with IGF-1. The downstream process of IGF-1 will then stop, and this will trigger cell apoptosis. Therefore, a reduction of neuronal cell apoptosis was indicated in the IGFBP3-injected OIR mice [69], and a larger retinal avascular zone was observed in the IGFBP3-deficient mice [70]. Jb3 is the inhibitor the of IGF-1 receptor. Similar to the action of IGFBP3, Jb3 bind to IGF-1 receptor and block its binding site of IGF-1. 
$\mathrm{Jb} 3$ injection in mouse model affected the vascularization and resulted in fewer neovascular tufts after hyperoxia-hypoxia induction [71]. Either induced or suppressed IGF level in ROP phase 1 or 2 have a beneficial effect on vascular development and maturation.

\subsection{Transcription Factors}

\subsubsection{Regulation of HIF-1 $\alpha$ Expression}

The increased or reduced HIF- $1 \alpha$ concentration is one way to attenuate the condition of vessel loss in phase 1 or neovascularization in phase 2, respectively. Prolyl hydroxylase (PHD) plays a role in the degradation of HIF- $1 \alpha$ and suppression of its activity. The PHD inhibitor, dimethyloxalylglycine (DMOG), and PHD2-deficient mice demonstrated an accumulation of HIF-1 $\alpha$ and prevention of vessel loss and vessel tufts in the early and late stage of OIR [72,73]. The suppression of HIF-1 $\alpha$ was also investigated using RTP801-deficient mice. RTP801 is a novel responsive gene of HIF-1. It is upregulated under hypoxia and induced the transcription of HIF-1. After OIR, RTP801-deficient mice displayed an attenuated neovascular tuft and decreased apoptosis [74]. Another method to reduce HIF effects is the direct inhibition of HIF by topotecan and doxorubicin that suppress the accumulation of HIF-1 $\alpha$ protein [94] and block HIF binding with its hypoxia-response element [95], respectively. Both inhibitors significantly decreased neovascular tufts in the mouse OIR model, and retinal function was further protected by topotecan treatment [96]. The use of upregulation or downregulation in HIF-1 $\alpha$ has a significant effect on suppression of ROP development.

\subsubsection{Inhibitory Effect of NOS Expression}

Inhibition of NOS can suppress cell proliferation and neovascular formation. For eliminating the NOS expression on phase 2 of ROP, the pretreatment of NOS inhibitors was investigated. $\mathrm{N}$-nitro-l-arginine (L-NA), $N^{\mathrm{G}}$-nitro-L-arginine (L-NNA), aminoguanidine (AG) were injected into the animal during hyperoxia [75-77]. L-NA and L-NNA are the general NOS inhibitors, and AG is the specific iNOS inhibitor. Studies demonstrated a reduction of the avascular zone and neovascular tufts in the NOS and iNOS inhibitor groups. The elimination of NOS expression plays a protective role in retinal damage.

\subsubsection{Blockage of $\beta$-ARs}

Vascular changes in ROP progression partially depend on $\beta$-AR concentration in the 2 phases of ROP. Propranolol is a nonselective $\beta$-AR antagonist. The vascular protective effect in propranolol is quite controversial. Subcutaneous injection $(0.02$ to $20 \mathrm{mg} / \mathrm{kg} /$ dose $)$ or topical administration ( 0.5 to $20 \mathrm{mg} / \mathrm{kg} / \mathrm{dose}$ ) of propranolol after hyperoxia resulted in an inhibition of neovasculature and VEGF expression [78,79]. Similarly, another investigation administrated propranolol (2 to $60 \mathrm{mg} / \mathrm{kg} / \mathrm{dose}$ ) after hyperoxia by oral, intraperitoneal, or subcutaneous injections [97]. However, these three propranolol-treated groups showed no significant difference in avascular and neovascular areas, as well as VEGF level. Moreover, a recent investigation in the use of propranolol in the mouse OIR model demonstrated an exacerbation of OIR where higher pericyte apoptosis and vascular permeability were observed [98]. On the other hand, the blockage of three $\beta$-ARs subtypes $\left(\beta_{1^{-}}, \beta_{2^{-}}\right.$and $\beta_{3}$ -ARs) using their respective specific inhibitor, atenolol, ICI 118,551 and SR59230A showed different results [80]. The $\beta_{2}$-AR blocker has a remarkable protection in vascular changes and a better retinal function after OIR. Therefore, the impact of using $\beta$-ARs blockers is still unclear, and more studies are required in investigating its protective properties after OIR.

\subsection{Anti-Angiogenesis}

Uncontrolled angiogenesis is a factor of neovascularization in phase 2 ROP. Anti-angiogenic agents provide a way to disrupt the vasculature formation pathway, thereby inhibiting abnormal neovasculature formation in ROP. 


\subsubsection{Steroid Agents}

Dexamethasone and anecortave acetate were identified as anti-angiogenic agents, but it may not be a suitable drug for ROP therapy. Dexamethasone and anecortave acetate were administrated in the mouse and rat OIR studies and showed a beneficial effect in neovascular suppression [81,82]. However, a recent clinical investigation mentioned that postnatal steroid use has a higher risk of severe ROP and fungal sepsis development [99]. Despite their roles as anti-angiogenic agents, dexamethasone and anecortave acetate are in fact independent risk factors of ROP severity.

\subsubsection{Other Angiogenic Inhibitors}

Some other anti-angiogenic agents have been discussed and exhibited the suppression of neovascular formation in rat or mouse OIR model. They have a common feature of suppression of VEGF, IGF-1, HIF- $1 \alpha$ and other angiogenic factors. For example, deguelin, YC-1 and $\beta$ - lapachone are the components that indirectly regulate the HIF-1 $\alpha$ expression [83-85]. Glial water channel aquaporin-4 (AQP4), linagliptin, furin and desmogleins are able to inhibit VEGF expression or its activity from reducing the effect of OIR [100-103]. N-terminal fragment of human prolactin (16K HPRL) and 12-lipoxygenase (12-LOX) mediate endothelial cell proliferation [86,87]. Tetramethylpyrazine (TMP), plasminogen kringle 5 (K5), myocyte enhancer factor $2 \mathrm{C}$ (MEF2C), anti-secretogranin III, mini-peptide ribosomal protein L41 (RPL41) and valproic acid have a protective and preventive effect in vascular diseases [88-90,104-106].

However, less information and investigations in ROP support was found for these anti-angiogenic components. More studies will be needed for further evaluating their protective effect on ROP.

\section{Neuroprotective Agents in ROP}

ROP can also be considered one of the neurodegeneration diseases, and it happens when the infants received supplementary oxygen therapy. The presence of hyperoxia-hypoxia induction is harmful to the retinal neurons due to the presence of oxidative stress. Moreover, the hypoxic damage causes the production of free radicals, inadequate blood supply and other inflammatory actions, as well as the apoptotic effect in neuronal cells [107]. Many investigations proposed the use of anti-oxidative and anti-inflammatory agents for possible prevention of neuronal apoptosis, and therefore, as treatments for ROP (Figure 1).

Moreover, recent evidence showed that neurodegeneration might occur before the vascular damage in diabetic retinopathy (DR) [108]. Similar to DR, ROP is also a kind of ischemic retinopathies. Although there is no any direct evidence showed that the progression of neovascularization in DR and ROP are the same, many researchers have studied retinal neovascularization in the proliferative DR using OIR model [8,15,109-114]. They may have a similar aspect of vascular changes in DR and ROP, but very limited studies have examined the association between neurodegeneration and vascular changes in OIR or ROP. Therefore, we hypothesize that neuroprotective agents may potentially be a promising therapeutic strategy for ROP.

\subsection{Antioxidants}

Antioxidants are the agents that have the ability to reduce oxidative stress. They can be divided into nutritional and systemic antioxidants. The antioxidants that can be obtained from the dietary sources are classified as nutritional antioxidants. Some food components have the properties of blocking the oxidative pathway or suppressing free radical production. Therefore, the consumption of these foods may prevent oxidative stress, and thus, neuronal damage. Another group of antioxidants is the agents that are present in the body and play a role in the inhibition of oxidative stress, but are suppressed in hypoxia naturally. Both nutritional and systemic antioxidant are critical components for suppressing oxidative stress and enhancing the ability of neuroprotection. 


\subsubsection{Nutritional Antioxidants}

Lutein

Lutein has an anti-oxidative effect on the ischemic and hypoxic models [115-119]. Lutein is a class of xanthophyll carotenoid and is contained in the dark vegetables and fruits, such as broccoli, kale and kiwi fruit. It cannot be generated in the body, and must, therefore, be ingested. Lutein is very safe. It is approved by the Food and Drug Administration (FDA) and considered as GRAS (generally recognized as safe). In the eye, it is present in the macula and lens, and acts as a photoprotective agent in screening out the harmful blue light $[120,121]$. Besides, lutein is an antioxidant and potential preventing agents for cataract and age-related macular degeneration (AMD) [120]. Photo-oxidative damage leads to protein oxidation, whose products can precipitate in the lens and results in cataract. Although there is a smaller amount of lutein concentrated in the lens (compared to the macula), it is possible to block the high energy blue light and prevent cataract. Similarly, in AMD, the presence of lutein suppresses the extent of photo-oxidation, and thus, reduces the formation of neovascularization $[120,122,123]$. In addition, lutein is shown to have anti-inflammatory properties in attenuating the activity of NF- $\mathrm{KB}[118,124]$. Lutein provides neuroprotective effects in both in vitro and in vivo studies. Higher cell viability and suppressed inflammatory responses were shown in the lutein-treated retinal ganglion cells (RGC-5) and rat Müller cells (rMC-1) after chemical-induced hypoxic damage [124,125]. It also prevents neuronal damage in mouse ischemia/reperfusion (I/R) injury model $[117,118,124]$, rat retinal detachment (RD) model [126] and rat $N$-methyl-d-aspartic acid (NMDA) retinal damage model [127]. When administrated $1 \mathrm{~h}$ before and $1 \mathrm{~h}$ after reperfusion in the I/R injury model, lutein treatment yielded a better neurological scoring, less brain damage, such as smaller infarct area and infarct volume, suppression of oxidative stress by inhibiting NFKB signaling pathway, and inhibition of apoptotic pathway by increasing phosphorylation of Akt and Bcl-2 expression. Lutein's retinal protective effect exhibited in the RD and NMDA models showed fewer TUNEL-positive cells, reduced GFAP immunoreactivity and inhibited apoptotic effect in RGC. In studies on the effect of lutein in the mouse OIR model, lutein was daily injected to mice during hypoxia. Interestingly, lutein treatment did not only reduce avascularization and vascular leakage, but also protected astrocytes and promoted the formation of endothelial tip cells [128]. Lutein may, therefore, be a potentially beneficial agent for maintaining vasculature and neuronal cells in human ROP.

\section{Caffeine}

Caffeine is commonly found in coffee, cola and tea. It serves as a stimulant in the central nervous system. Its anti-oxidative characteristic was first described in 1991 [129]. Earlier investigations mentioned the protective effect in the inhibition of oxidative DNA damage, attenuation of oxidative stress in rat liver and anti-inflammation by regulating TNF-alpha production [130-133]. In addition, caffeine (when cotreated with adenosine A2A receptor antagonists) displayed a neuroprotective effect by acting against $\beta$-amyloid-induced neurotoxicity in an in vitro AD study [134]. Recently, the neuroprotective effect of caffeine was indicated using a rat hyperoxia injury model where caffeine was injected intraperitoneally before exposure to $80 \%$ oxygen environment [135]. Fewer TUNEL-positive neuronal cells were observed in the caffeine-treated immature brain samples. Caffeine was then investigated in the mouse OIR model. The water-soluble caffeine was administered by addition to the drinking water. This treatment did not affect normal vascular development, but it could eliminate avascular area and neovascular tufts. The concentration of VEGF was significantly lower than that in the untreated group with a lower apoptotic response in neuronal cells after treatment [136]. Caffeine, therefore, has a beneficial effect on the prevention of neuronal damage in OIR. However, the adverse and long-term effect of caffeine in premature infants are not discussed; this can potentially cause caffeine addiction after treatment. 
Omega-3 Long-Chain Polyunsaturated Fatty Acids ( $\omega-3$ PUFAs)

Long-chain eicosapentaenoic (EPA) and docosahexaenoic (DHA) fatty acids are the $\omega$-3 PUFAs that have a beneficial effect of oxidative stress prevention. Omega-3 is enriched in fish oil. The protection of neuronal cells using $\omega-3$ PUFAs has been shown in many neurodegeneration diseases, such as AD and PD. In the epidemiological studies conducted in France and Chicago, participants who have a higher consumption of fish or DHA have a lower risk of dementia or AD [137-139]. To further understand the effect of PUFAs, transgenic mouse model, Tg2576 mouse, was generated for investigation of neurodegeneration in AD. The DHA-treated mice have a lower apoptotic response and fewer behavioral deficits in the swimming behavioral test [140]. After that, the protective effect of $\omega-3$ PUFAs and DHA was investigated in the in vitro RGC-5 cells or in vivo mouse OIR model. RGC-5 cells were protected by DHA under $\mathrm{H}_{2} \mathrm{O}_{2}$-induced oxidative stress by inhibition of apoptosis [141]. In the animal studies, the diet was mixed with $\omega-3$ PUFAs and fed to the lactating mother during hyperoxia. Neovascularization was significantly inhibited after $\omega-3$ PUFAs treatment [142-144]. Although the neuroprotective effect of EPA and DHA was showed in the in vitro RGC cells, it is essential that more studies are required to support its neuroprotective effect in the in vivo OIR models.

\section{Resveratrol}

Resveratrol is a phytoalexin that can be absorbed from the dietary sources, such as grapes, berries, and peanuts. It is a natural antioxidant by reducing the generation of ROS and maintaining the concentration of intracellular antioxidants [145-147]. Other than being an antioxidant, it also contains anti-inflammatory properties $[148,149]$. It provided a neuroprotective role in animal models for AD, PD, and stroke [146,150-155]. Decreased apoptosis of neuronal cells and prevention of motor impairment were observed in the animal models for these neurodegenerative diseases. Resveratrol also showed a beneficial effect in in vitro and in vivo rat OIR studies. Resveratrol was provided during hyperoxia in the in vitro OIR primary culture study that resulted in I attenuated eNOS and nNOS levels after treatment [156]. It was then further investigated in a rat OIR model. Resveratrol injection was performed either during hyperoxia or after hyperoxia intragastrically. The concentration of eNOS and nNOS, as well as Bcl-2 expression, were suppressed in the resveratrol-treated groups $[156,157]$. Resveratrol might have an anti-angiogenic effect in the OIR model by inhibiting the several angiogenic factors. Despite resveratrol's potential neuroprotective properties in AD, PD and stroke models, there is a lack of information for its beneficial effects in OIR models.

\section{Vitamin E}

Vitamin E is a well-known fat-soluble antioxidant and is commonly found in vegetable oil, meat and eggs. It can serve as a supplement for preventing cancer and heart disease, as well as treating diabetes. The neuroprotection pathway of vitamin $\mathrm{E}$ was still unclear, but the suppression of neurodegeneration has been shown in several studies. Neuronal damage was reduced in the animal ischemic model [158], and the suppression of AD progression was observed in a clinical trial [159]. More importantly, protective effects were first observed in the OIR model in 1977. Vitamin E was administrated to the pups by intraperitoneal injection or fed to their mother during hyperoxia $[160,161]$. The retinal vasculature of the pups had a much smaller avascular area after hyperoxia induction. In a clinical trial, there was also a reduction of ROP incidence after vitamin $E$ treatment, and no adverse effects were identified [162-165]. However, there is currently no data to support the neuroprotective role of vitamin $\mathrm{E}$ in OIR, despite its well-established effects in the central nervous system.

\subsubsection{Endogenous Antioxidants}

Suppression of Aldose Reductase

Aldose reductase is the first enzyme in the polyol pathway which converts glucose to sorbitol. Upregulation of polyol pathway directly induces oxidative stress under hyperglycemic 
condition [112,166-170]. Inhibition of aldose reductase has a protective effect on diabetic and ischemic models by reducing oxidative stress and VEGF expression, as well as preventing BRB breakdown [171-174]. In OIR, inhibition of aldose reductase expression and its association with OIR has been investigated using aldose reductase-deficient mouse model or administration of an aldose reductase inhibitor, Fidarestat $[175,176]$. The absence of aldose reductase in the mice does not affect normal retinal development, including vasculature, function and morphology. Interestingly, there was attenuation of avascular and neovascular areas and prevention of vessel leakage in the ganglion cell layer and outer plexiform layer in the aldose reductase-deficient mice and Fidarestat-treated retinae after OIR. Lower expression of proinflammatory response protein $\mathrm{p}-\mathrm{I}_{\mathrm{K}} \mathrm{B}$ and cell proliferative signaling molecular, such as VEGF and p-Akt was found with a milder GFAP immunoreactivity and microglial activation. More importantly, the absence of aldose reductase preserved retinal function after OIR. This neuroprotective role of aldose reductase deficiency in the OIR model was reflected in its anti-oxidative and anti-inflammatory events, thereby attenuating glial cell responses and neuronal cell death.

\section{Superoxide Dismutase (SOD)}

SOD is a water-soluble endogenous enzyme with anti-oxidative effect. It is the first line of oxidation defense by reduction of superoxide radicals. Natural SOD has large molecular weight, a short life-span, and lower availability in circulation. For prolonged life-span and increased activity, SOD is usually modified before exhibiting its protective effects, such as nonpeptidyl Mn-based SOD (MnSOD), liposomal SOD, and copper-zinc SOD (CuZnSOD) [177-180]. Neuroprotection by SOD was shown in the mouse stroke model of transient occlusion of the middle cerebral artery (MCAO) $[177,179,181]$. Mice after MCAO have an improvement of neurobehavioral outcome and reduction of infarct volume after injection of SOD mimetics and MnSOD. Furthermore, there was a reduction of intracellular superoxide radical concentration, and a increase in neuronal cell viability in in vitro primary culture. The effect of SOD overexpression was evaluated in mouse OIR model by the transgene of SOD gene or intraperitoneal injection of liposomal SOD and CuZuSOD $[178,180]$. These investigations showed no adverse effect in normal retinal development, but reduced avascular and neovascular areas after hyperoxia-hypoxia induction. Therefore, the anti-oxidation property of SOD provides prevention of ROP progression, but its effects on the retinal neurons, and hence, neuroprotection properties remain unclear.

Statin

Statin is a lipid-lowering drug that can prevent cardiovascular diseases [182]. It suppresses HMG-CoA reductase, the enzyme for biosynthesis of cholesterol [183]. Its prevention of neuronal cell death has been shown in both cell culture and animal studies. However, statin has a dose-dependent neuroprotective or neurotoxic effect in different studies [184]. Therefore, consideration of statin concentration becomes a critical part of treatment. Simvastatin, lovastatin, atorvastatin and fluvastatin are the common statins that are used as drug treatment for hypercholesterolemia [185]. Simvastatin $(50 \mathrm{mg} / \mathrm{kg} /$ day $)$ treatment caused an upregulation of Bcl-2 in gene and protein level and promoted an anti-apoptotic effect in mice and guinea pig AD model [186,187]. Fluvastatin, when administrated to the mouse intraperitoneally $(10 \mathrm{mg} / \mathrm{kg} / \mathrm{day})$, suppressed the formation of retinal neovascularization, expression of VEGF, HIF-1 $\alpha$, inflammatory mediator ICAM-1, and elimination of superoxide production [188]. These studies showed that statin plays an anti-oxidative, anti-inflammatory and anti-angiogenic role in the OIR models; however, there is no mention of any protective effects on the retinal neurons.

\section{Melatonin}

Melatonin is a neurohormone derived from the pineal gland and is widely used in clinical applications. It provides regulation of normal body rhythms as a sleep aid supplement. Melatonin 
also contributes to stroke and some neurological disorders, including AD and PD. Melatonin-treated rats showed significantly reduced inflammatory responses, BRB permeability, and formation of cerebral edema after experimental stroke [189-192]. It also has a protective effect in neurodegeneration diseases by acting as a free radical scavenger. The anti-oxidative activity of melatonin is shown in the reduction of free radical and upregulation of antioxidant enzyme, including SOD, glutathione peroxidase and glucose-6-phosphate dehydrogenase [193-195]. Melatonin also provides beneficial effects in hypoxia-induced rat model and mouse OIR model [196,197]. Melatonin could reduce neovascularization by suppressing VEGF and HIF- $1 \alpha$ secretions. Besides its role as a regulatory hormone, melatonin also offers neuroprotection in stroke and neurodegeneration. Unfortunately, its neuroprotective effects in the OIR model have not been investigated.

Apocynin

Apocynin is a $\mathrm{NAD}(\mathrm{P}) \mathrm{H}$ oxidase inhibitor, which was first isolated from Apocynum species. There is a direct relationship between $\mathrm{NAD}(\mathrm{P}) \mathrm{H}$ oxidase, ROS production, oxidative stress and progression of neurodegenerative disorders. $\mathrm{NAD}(\mathrm{P}) \mathrm{H}$ oxidase is the major source of ROS production. The accumulation of ROS leads to oxidative stress and causes neuronal damage, resulting eventually in neurodegenerative diseases. By inhibiting $\mathrm{NAD}(\mathrm{P}) \mathrm{H}$ oxidase, apocynin suppresses oxidative stress and prevents neurodegeneration [198]. Apocynin is a powerful blocker for $\mathrm{NAD}(\mathrm{P}) \mathrm{H}$ oxidase. It is easily oxidized by peroxidases and forms dimer or trimer derivatives [198]. The neuroprotective function of apocynin was well described in stroke and PD studies by yielding a better neurological outcome and reduction of oxidative stress and inflammatory responses [199-204]. The administration of apocynin has been proposed for treating OIR mice $[205,206]$. When administered by intraperitoneal injection after hyperoxia, beneficial effects in vascular protection, including suppression of neovascular formation and VEGF concentration were observed. Apocynin exhibits a protective effect in the OIR model as an indirect suppressor for oxidative stress, but no information is available on its neuroprotective roles in OIR.

\subsection{Anti-Inflammatory Agents}

\subsubsection{Prostaglandin Inhibitors}

Indomethacin and ibuprofen are nonsteroidal anti-inflammatory agents and prostaglandin inhibitors. Many studies using these prostaglandin inhibitors are carried out for treating patent ductus arteriosus (PDA). PDA is a common heart disease in preterm infants, and it increases the risk of pulmonary hemorrhage, necrotizing enterocolitis (NEC) and intraventricular hemorrhage [207]. These prostaglandin inhibitors inhibit cyclooxygenase (COX), which can induce inflammatory cells. Other than the anti-inflammatory effect, they also exhibited the neuroprotective effect in brain injury and PD diseases by suppressing neuronal apoptosis, lipid peroxidation and superoxide production [208-212]. Specifically, subcutaneous administration of indomethacin and ibuprofen provides vascular protection in OIR $[213,214]$. The size of the neovascular area was significantly inhibited in the drug-treated OIR mice. These prostaglandin inhibitors not only provide a neuroprotective effect on brain injury and PD, but also play a role in vascular protection in OIR. Unfortunately, whether they can exert neuroprotective effects in OIR remains unclear.

\subsubsection{Granulocyte Colony-Stimulating Factor (G-CSF)}

G-CSF is a well-known hematopoietic glycoprotein. It stimulates proliferation, survival and maturation of cells [215]. Many studies indicated that G-CSF promotes anti-inflammatory, anti-apoptotic and neuroprotective effects [216-220]. The presence of G-CSF reduces inflammatory responses and neuronal cell damage in both in vitro and in vivo rodent ischemic models. These beneficial effects were also shown in the $\mathrm{H}_{2} \mathrm{O}_{2}$ induced human retinal endothelial cell culture and mouse OIR model [221]. OIR-treated mice, receiving an intravitreal injection of G-CSF after hyperoxia, displayed suppressed 
neovascularization. Although G-CSF could suppress neuronal damage in ischemia models, there is limited data on its neuroprotection in the OIR model.

\subsection{Others}

Inhibition of Renin-Angiotensin System (RAS)

RAS regulates angiogenesis. Renin and angiotensin II type-1 receptor (AT1-R) play potential roles to either induce or suppress cell proliferation path in RAS. Renin is the initiation enzyme of RAS. Aliskiren, a renin inhibitor to attenuate renin secretion, was injected to the OIR-treated mice after hyperoxia [222]. Reduced retinal neovascularization and suppressed VEGF mRNA and protein level were observed in the aliskiren-treated OIR mice. In addition, other investigations suggested that blockage of AT1-R is another possible therapy for anti-angiogenesis in ROP, as AT1-R can stimulate cell proliferation, fibrosis, and angiogenesis. Valsartan is an AT1-R inhibitor [223,224]. After valsartan treatment by intraperitoneal injection in the rat, it prevented the neovascular formation and had a neuroprotective effect. Treatment with valsartan yielded an extensive glial vascular network and enhanced astrocytes coverage in the retina after OIR, indicating that blockage of RAS may be a potential therapy for ROP.

\section{Stem Cell Therapy in ROP}

Stem cell therapy is now a popular approach to treat a disease. Stem cells (SCs) have the characteristics of differentiating into specialized cell types with unlimited renewing properties [225]. These properties provide great potentials for therapeutic uses in tissue repair and regeneration. In the eye, identification of ocular SCs first started in the 1970s. The ocular SCs are region-specific and are commonly found in the limbus, conjunctiva and trabecular meshwork [226]. Later, a clinical study investigated SC populations in peripheral blood samples from preterm babies with or without ROP [227]. Two SC populations were found to be upregulated in preterm babies and babies with ROP. They are very small embryonic-like stem cells (VSEL-SCs, $\mathrm{Lin}^{-} \mathrm{CXCR} 4^{+} \mathrm{CD} 45^{-}$) and endothelial progenitor cells (EPCs, CD $34^{+} \mathrm{CD} 133^{+} \mathrm{CD} 144^{+}$), respectively. VSEL-SCs express the early embryonic transcription factors and play a role in embryogenesis. Clinical studies indicated that the mobilization of VSEL-SCs is activated in some hypoxic-related injuries, such as acute myocardial infarction and stroke, and accumulated in peripheral blood $[228,229]$. However, the actual role of VSEL-SCs in tissue repair is still unknown. On the other hand, EPCs are responsible for tissue repair. EPCs can differentiate into endothelial cells, and they can be transported from bone marrow to the site of injury through circulation [227]. The findings that mobilization of systemic EPCs is upregulated during normal vascular development without ROP and in the proliferative phase of ROP suggested that a specific SC mobilization is associated with ROP progression.

In fact, different populations of SCs have been shown to promote retinal vascular repair in the mouse OIR model. Adult mouse bone marrow (BM)-derived lineage negative ( $\mathrm{Lin}^{-}$) or CD44 ${ }^{\text {hi }}$ myeloid progenitor cells are the first SC populations that are investigated in OIR [230]. This study demonstrated that adult BM derived myeloid progenitor cells could migrate to the avascular zone in the retina and differentiate into microglia. Moreover, these SCs did not only reduce avascular and neovascular areas after injection, but also accelerated retinal revascularization. Retinal morphology and function were also examined for the long-term effect after transplantation. No abnormal retinal structure and function were observed between injected eyes and control eyes at six months after injection. Another study of SCs in OIR used two main subtypes of EPC, early EPCs (eEPCs) and outgrowth endothelial cells (OECs) [231]. Their proliferative potential was investigated in the in vitro culture. The lower proliferative property was shown in the eEPCs comparing with OECs, although both displayed the classical EPC phenotypes, such as bound lectin and expressed CD31. Furthermore, OECs have a higher expression of VEGFR-2 and promote cell monolayer formation with intercellular junctions. Although both eEPCs and OECs yielded EPC phenotypes, only OECs are closely related to endothelial 
cells by displaying tight junctions and association with retinal vascular formation in the in vitro study. OECs were then injected intravitreally after hyperoxia for further investigation on the role of OECs in the OIR model. Injected eyes displayed a significantly reduced avascular area and prevention of neovascularization. Other than eEPC and OEC, the effect of mesenchymal stem cells (MSCs) and adipose-derived stem cells (ASCs) were reported recently using the mouse OIR model [232-235]. MSCs or ASCs were injected into the OIR-treated mice at P12 intravitreally. The injection of MSCs did not only protect the retinal vessels by reducing avascular and neovascular areas, but also inhibited inflammatory activity. Lower expression of proinflammatory cytokines, such as IL- $1 \beta$ and TNF $\alpha$, and increased anti-inflammatory cytokines, including IL-10 and IL-4, was observed. On the other hand, the ASC-injected pups displayed a positive effect in retinal morphology by increase the retinal vascular area after OIR. Despite its therapeutic potential in protecting vasculature and inhibiting inflammation in the OIR model, effects of SCs on retinal neuronal morphology and function are not studied and reported. Therefore, more investigations are needed for stability, efficacy and side effects of SC therapy in the developing infant eye.

\section{Current Treatments in ROP}

Current treatments for ROP aim to control and eliminate the pathological neovascularization; they include cryotherapy, laser photocoagulation and anti-VEGF therapy [236]. Retinal cryotherapy and laser coagulation involve ablation of the peripheral avascular retina [237]. Cryotherapy was first described as a treatment for severe ROP patients in the late 1980s. It is an effective treatment, yielding more than $40 \%$ reduction of unfavorable functional outcomes in the cryotherapy-treated eye of severe ROP infants in 3-month, 10-year and 15-year follow-up CRYO-ROP studies [238-240]. However, complications appeared with cryotherapy, such as conjunctival laceration, lid edema, apnea, and vitreous hemorrhage, as well as new retinal detachment $[9,226,240]$. For the better structural and functional outcomes, laser therapy emerged with less ocular and systemic side effects $[9,226,241]$. It has a lower requirement in general anesthesia. However, some complications about laser treatment are substantial, such as cataract, intraocular hemorrhage, and cornea and lens burn [226]. Ablative therapy has an effective outcome in ablation of peripheral avascular retina after treatment, but it may occur with systemic complications or unfavorable structural and functional outcomes.

It has been shown that upregulation of VEGF in the progression of ROP causes retinal neovascularization. Recently, extensive research has been focused on controlling VEGF concentration during hypoxia. Intravitreal injection of anti- VEGF antibody has been performed to normalize the excess VEGF. Bevacizumab, ranibizumab and aflibercept are the anti-VEGF antibodies that underwent ROP clinical trials since 2011. Reduced retinal vascular tortuosity, and in turn, regression of vessel growth toward peripheral retina were observed after injection [54,61]. The side effects that are observed laser in ablative therapy, such as retinal scarring and cataract are eliminated. However, other clinical trials reported that the injected anti-VEGF antibodies could enter the systemic circulation through the damaged BRB, and in turn, reduce the systemic VEGF amount $[55,56]$, which may affect the development of the infants. Therefore, long-term studies in using anti-VEGF treatment for ROP infants are essential for preventing neurodevelopment disruption in their childhood.

Combination treatment of laser coagulation and anti-VEGF injection has now become a new trend of ROP treatment. Previous clinical studies in combination therapy have a positive and effective outcome for ROP patients $[57,58,62,217]$. Regression of peripheral retinal vessel, while no signs of ocular and systemic side effects were observed after bevacizumab injection and laser treatment during the 8-week, 3-month and 6-month follow-up period [57,58,217]. Another clinical trial using ranibizumab injection with laser therapy showed regression of ROP without any unfavorable ocular outcome [62]. In fact, the combined therapy of anti-VEGF injection and laser coagulation may require a lower anti-VEGF dose, thereby minimizing the systemic drop of VEGF level after therapy with a better outcome. However, long-term study about the efficacy and adverse effects of therapy are necessary. 


\section{Conclusions and Future Perspectives}

Since 1942 when ROP was first described, many therapeutic options in inhibiting VEGF actions have been proposed and provided retinal vascular protective effects. Unfortunately, the protection of retinal neurons in OIR and ROP attracts little attention. Many antioxidants, anti-inflammatory agents and other factors could be the targets of neuroprotection. However, despite their availability, there have been very limited investigations in OIR and ROP that focused on the preservation of neuronal structure and function using these agents. Future studies should be conducted in deciphering the relationship between vascular changes and neurodegeneration in ROP and functional and morphological changes in neuronal cells, as well as glial cells, so as to preserve vision in babies with ROP, a lifelong medical condition and a major public health issue.

Funding: This research was funded by Health and Medical Research Fund, the Food and Health Bureau, The Government of the Hong Kong Special Administrative Region (05163526), Germany/Hong Kong Joint Research Scheme 2017/2018 (G-HKU705/17) and The University of Hong Kong Seed Funding Program for Basic Research (201611159155).

Conflicts of Interest: The authors declare no conflict of interest.

\section{Abbreviations}

$\begin{array}{ll}5^{\prime} \text { N } & 5^{\prime} \text { nucleotidase } \\ \text { AD } & \text { Alzheimer's disease } \\ \text { AMD } & \text { Age-related macular degeneration } \\ \text { AT1-R } & \text { Angiotensin II type-1 receptor } \\ \beta-A R & \beta \text {-adrenergic receptor } \\ \text { BRB } & \text { Blood-retinal barrier } \\ \text { COX } & \text { Cyclooxygenase } \\ \text { DHA } & \text { Docosahexaenoic } \\ \text { DR } & \text { Diabetic retinopathy } \\ \text { EPA } & \text { Eicosapentaenoic } \\ \text { eEPC } & \text { Early endothelial progenitor cells } \\ \text { Epo } & \text { Erythropoietin } \\ \text { FDA } & \text { Food and Drug Administration } \\ \text { G-CSF } & \text { Granulocyte colony-stimulating factor } \\ \text { HIF } & \text { Hypoxia-inducible factor } \\ \text { HRE } & \text { Hypoxia response element } \\ \text { HSPG } & \text { Heparin sulphate proteoglycans } \\ \text { IGF-1 } & \text { Insulin-like growth factor-1 } \\ \text { KDR } & \text { Kinase insert domain-containing receptor } \\ \text { KLT-1 } & \text { Kms-related tyrosine kinase 1 } \\ \text { mTOR } & \text { Mammalian target of rapamycin } \\ \text { NOS } & \text { Nitric oxide synthetase } \\ \text { NRP } & \text { Neurophilin } \\ \omega-3 \text { PUFAs } & \text { Omega-3 long-chain polyunsaturated fatty acids } \\ \text { OIR } & \text { Oxygen-induced retinopathy } \\ \text { OPC } & \text { Outgrowth endothelial cells } \\ \text { PD } & \text { Parkinson's disease } \\ \text { PHD } & \text { Prolyl hydroxylase } \\ \text { RAS } & \text { Renin-angiotensin system } \\ \text { RGC } & \text { Retinal ganglion cells } \\ \text { ROP } & \text { Retinopathy of prematurity } \\ \text { ROS } & \text { Reactive oxygen species } \\ \text { SC } & \text { Stem cell } \\ \text { SRPK1 } & \text { Serine arginine protein kinase 1 } \\ \text { SRSF1 } & \text { Serine-rich splicing factor-1 } \\ \text { STOP-ROP } & \text { Supplemental Therapeutic Oxygen for Prethreshold Retinopathy Of Prematurity } \\ \text { VEGF } & \text { Vascular endothelial growth factor } \\ & \end{array}$




\section{References}

1. Terry, T.L. Extreme prematurity and fibroblastic overgrowth of persistent vascular sheath behind each crystalline lens: I. Preliminary report. Am. J. Ophthalmol. 1942, 25, 203-204. [CrossRef]

2. Jain, V.; Langham, M.C.; Wehrli, F.W. MRI estimation of global brain oxygen consumption rate. Br. J. Pharmacol. 2010, 30, 1987.

3. Anderson, B.; Saltzman, H.A. Retinal Oxygen Utilization Measured by Hyperbaric Blackout. Arch. Ophthalmol. 1964, 72, 792-795. [CrossRef] [PubMed]

4. Anderson, B., Jr. Ocular effects of changes in oxygen and carbon dioxide tension. Trans. Am. Ophthalmol. Soc. 1968, 66, 423. [PubMed]

5. Nag, T.; Wadhwa, S. Morphological and Neurochemical Development of the Human Neural Retina. Neuroembryol. Aging 2006, 4, 19-30. [CrossRef]

6. Weidman, T.A. Fine Structure of the Developing Retina. Int. Ophthalmol. Clin. 1975, 15, 65-84. [CrossRef] [PubMed]

7. Van Cruchten, S.; Vrolyk, V.; Lepage, M.-F.P.; Baudon, M.; Voute, H.; Schoofs, S.; Haruna, J.; Benoit-Biancamano, M.-O.; Ruot, B.; Allegaert, K.; et al. Pre- and Postnatal Development of the Eye: A Species Comparison. Birth Defects Res. 2017, 109, 1540-1567. [CrossRef] [PubMed]

8. Scott, A.; Fruttiger, M. Oxygen-induced retinopathy: A model for vascular pathology in the retina. Eye 2010, 24, 416-421. [CrossRef] [PubMed]

9. Liu, J.; Lai, C.H.; Lo, A.C. Therapeutic strategies for retinopathy of prematurity. Hong Kong J. Ophthalmol. 2015, 19, 8-15.

10. Group, S.-R.M.S. Supplemental therapeutic oxygen for prethreshold retinopathy of prematurity (STOP-ROP), a randomized, controlled trial. I: Primary outcomes. Pediatrics 2000, 105, 295-310.

11. Chen, J.; Smith, L.E. Retinopathy of prematurity. Angiogenesis 2007, 10, 133-140. [CrossRef]

12. Hellström, A.; LSmith, E.; Dammann, O. Retinopathy of prematurity. Lancet 2013, 382, 1445-1457. [CrossRef]

13. Sapieha, P.; Joyal, J.-S.; Rivera, J.C.; Kermorvant-Duchemin, E.; Sennlaub, F.; Hardy, P.; Lachapelle, P.; Chemtob, S. Retinopathy of prematurity: Understanding ischemic retinal vasculopathies at an extreme of life. J. Clin. Investig. 2010, 120, 3022-3032. [CrossRef]

14. Tin, W.; Gupta, S. Optimum oxygen therapy in preterm babies. Arch. Dis. Child. Fetal Neonatal Ed. 2007, 92, F143-F147. [CrossRef] [PubMed]

15. Connor, K.M.; Krah, N.M.; Dennison, R.J.; Aderman, C.M.; Chen, J.; Guerin, K.I.; Sapieha, P.; Stahl, A.; Willett, K.L.; Smith, L.E.H. Quantification of oxygen-induced retinopathy in the mouse: A model of vessel loss, vessel regrowth and pathological angiogenesis. Nat. Protoc. 2009, 4, 1565-1573. [CrossRef] [PubMed]

16. Alon, T.; Hemo, I.; Itin, A.; Pe'Er, J.; Stone, J.; Keshet, E. Vascular endothelial growth factor acts as a survival factor for newly formed retinal vessels and has implications for retinopathy of prematurity. Nat. Med. 1995, 1, 1024-1028. [CrossRef] [PubMed]

17. Mintz-Hittner, H.A.; Kennedy, K.A.; Chuang, A.Z. Efficacy of intravitreal bevacizumab for stage 3+ retinopathy of prematurity. N. Engl. J. Med. 2011, 364, 603-615. [CrossRef] [PubMed]

18. Sato, T.; Wada, K.; Arahori, H.; Kuno, N.; Imoto, K.; Iwahashi-Shima, C.; Kusaka, S. Serum Concentrations of Bevacizumab (Avastin) and Vascular Endothelial Growth Factor in Infants with Retinopathy of Prematurity. Am. J. Ophthalmol. 2012, 153, 327-333. [CrossRef]

19. Wu, W.-C.; Shih, C.-P.; Lien, R.; Wang, N.-K.; Chen, Y.-P.; Chao, A.-N.; Chen, K.-J.; Chen, T.-L.; Hwang, Y.-S.; Lai, C.-C. Serum vascular endothelial growth factor after bevacizumab or ranibizumab treatment for retinopathy of prematurity. Retina 2017, 37, 1-701. [CrossRef]

20. Chung, E.J.; Kim, J.H.; Ahn, H.S.; Koh, H.J. Combination of laser photocoagulation and intravitreal bevacizumab (Avastin ${ }^{\circledR}$ ) for aggressive zone I retinopathy of prematurity. Graefe's Arch. Clin. Exp. Ophthalmol. 2007, 245, 1727-1730. [CrossRef]

21. Kim, J.; Kim, S.J.; Chang, Y.S.; Park, W.S. Combined intravitreal bevacizumab injection and zone I sparing laser photocoagulation in patients with zone I retinopathy of prematurity. Retina 2014, 34, 77-82. [CrossRef] [PubMed]

22. Martínez-Castellanos, M.A.; Schwartz, S.; Hernández-Rojas, M.L.; Kon-Jara, V.A.; García-Aguirre, G.; Guerrero-Naranjo, J.L.; Chan, R.V.P.; Quiroz-Mercado, H. Long-term effect of antiangiogenic therapy for retinopathy of prematurity up to 5 Years of Follow-up. Retina 2013, 33, 329-338. [CrossRef] [PubMed] 
23. Morin, J.; Luu, T.M.; Superstein, R.; Ospina, L.H.; Lefebvre, F.; Simard, M.-N.; Shah, V.; Shah, P.S.; Kelly, E.N.; The Canadian Neonatal Network and the Canadian Neonatal Follow-Up Network Investigators. Neurodevelopmental Outcomes Following Bevacizumab Injections for Retinopathy of Prematurity. Pediatrics 2016, 137, e20153218. [CrossRef] [PubMed]

24. Castellanos, M.A.M.; Schwartz, S.; García-Aguirre, G.; Quiroz-Mercado, H. Short-term outcome after intravitreal ranibizumab injections for the treatment of retinopathy of prematurity. Br. J. Ophthalmol. 2013, 97, 816-819. [CrossRef] [PubMed]

25. Mota, Á.; Carneiro, Â.; Breda, J.; Rosas, V.; Magalhães, A.; Silva, R.; Falcão-Reis, F. Combination of Intravitreal Ranibizumab and Laser Photocoagulation for Aggressive Posterior Retinopathy of Prematurity. Case Rep. Ophthalmol. 2012, 3, 136-141. [CrossRef] [PubMed]

26. Tokunaga, C.C.; Mitton, K.; Dailey, W.; Massoll, C.; Roumayah, K.; Guzmán, E.; Tarabishy, N.; Cheng, M.; Drenser, K.A. Effects of Anti-VEGF Treatment on the Recovery of the Developing Retina Following Oxygen-Induced Retinopathy. Investig. Opthalmology Vis. Sci. 2014, 55, 1884-1892. [CrossRef]

27. Jiang, Y.; Wang, H.; Culp, D.; Yang, Z.; Fotheringham, L.; Flannery, J.; Hammond, S.; Kafri, T.; Hartnett, M.E. Targeting Müller Cell-Derived VEGF164 to Reduce Intravitreal Neovascularization in the Rat Model of Retinopathy of Prematurity. Investig. Opthalmol. Vis. Sci. 2014, 55, 824-831. [CrossRef]

28. McLeod, D.S.; Taomoto, M.; Cao, J.; Zhu, Z.; Witte, L.; Lutty, G.A. Localization of VEGF receptor-2 (KDR/Flk-1) and effects of blocking it in oxygen-induced retinopathy. Investig. Ophthalmol. Vis. Sci. 2002, 43, 474-482.

29. Gammons, M.V.; Dick, A.D.; Harper, S.J.; Bates, D.O. SRPK1 inhibition modulates VEGF splicing to reduce pathological neovascularization in a rat model of retinopathy of prematurity. Investig. Ophthalmol. Vis. Sci. 2013, 54, 5797-5806. [CrossRef]

30. Yagasaki, R.; Nakahara, T.; Ushikubo, H.; Mori, A.; Sakamoto, K.; Ishii, K. Anti-angiogenic Effects of Mammalian Target of Rapamycin Inhibitors in a Mouse Model of Oxygen-Induced Retinopathy. Boil. Pharm. Bull. 2014, 37, 1838-1842. [CrossRef]

31. Vanhaesebrouck, S.; Daniëls, H.; Moons, L.; Vanhole, C.; Carmeliet, P.; De Zegher, F. Oxygen-Induced Retinopathy in Mice: Amplification by Neonatal IGF-I Deficit and Attenuation by IGF-I Administration. Pediatr. Res. 2009, 65, 307-310. [CrossRef] [PubMed]

32. Löfqvist, C.; Chen, J.; Connor, K.M.; Smith, A.C.H.; Aderman, C.M.; Liu, N.; Pintar, J.E.; Ludwig, T.; Hellström, A.; Smith, L.E.H. IGFBP3 suppresses retinopathy through suppression of oxygen-induced vessel loss and promotion of vascular regrowth. Proc. Natl. Acad. Sci. USA 2007, 104, 10589-10594. [CrossRef] [PubMed]

33. Kielczewski, J.L.; Hu, P.; Shaw, L.C.; Calzi, S.L.; Mames, R.N.; Gardiner, T.A.; McFarland, E.; Chan-Ling, T.; Grant, M.B. Novel Protective Properties of IGFBP-3 Result in Enhanced Pericyte Ensheathment, Reduced Microglial Activation, Increased Microglial Apoptosis, and Neuronal Protection after Ischemic Retinal Injury. Am. J. Pathol. 2011, 178, 1517-1528. [CrossRef] [PubMed]

34. Smith, L.E.H.; Shen, W.; Perruzzi, C.; Soker, S.; Kinose, F.; Xu, X.; Robinson, G.; Driver, S.; Bischoff, J.; Zhang, B.; et al. Regulation of vascular endothelial growth factor-dependent retinal neovascularization by insulin-like growth factor-1 receptor. Nat. Med. 1999, 5, 1390-1395. [CrossRef] [PubMed]

35. Sears, J.E.; Hoppe, G.; Ebrahem, Q.; Anand-Apte, B. Prolyl hydroxylase inhibition during hyperoxia prevents oxygen-induced retinopathy. Proc. Natl. Acad. Sci. USA 2008, 105, 19898-19903. [CrossRef] [PubMed]

36. Duan, L.-J.; Takeda, K.; Fong, G.-H. Prolyl Hydroxylase Domain Protein 2 (PHD2) Mediates Oxygen-Induced Retinopathy in Neonatal Mice. Am. J. Pathol. 2011, 178, 1881-1890. [CrossRef] [PubMed]

37. Brafman, A.; Mett, I.; Shafir, M.; Gottlieb, H.; Damari, G.; Gozlan-Kelner, S.; Vishnevskia-Dai, V.; Skaliter, R.; Einat, P.; Faerman, A.; et al. Inhibition of Oxygen-Induced Retinopathy in RTP801-Deficient Mice. Investig. Opthalmol. Vis. Sci. 2004, 45, 3796-3805. [CrossRef]

38. Beauchamp, M.H.; Sennlaub, F.; Speranza, G.; Gobeil, F.; Checchin, D.; Kermorvant-Duchemin, E.; Abran, D.; Hardy, P.; Lachapelle, P.; Varma, D.R.; et al. Redox-dependent effects of nitric oxide on microvascular integrity in oxygen-induced retinopathy. Free. Radic. Boil. Med. 2004, 37, 1885-1894. [CrossRef]

39. Brooks, S.E.; Gu, X.; Samuel, S.; Marcus, D.M.; Bartoli, M.; Huang, P.L.; Caldwell, R.B. Reduced severity of oxygen-induced retinopathy in eNOS-deficient mice. Investig. Ophthalmol. Vis. Sci. 2001, 42, 222-228.

40. Zhang, Q.; Zhang, J.; Guan, Y.; Zhang, S.; Zhu, C.; Xu, G.-T.; Wang, L. Suppression of retinal neovascularization by the iNOS inhibitor aminoguanidine in mice of oxygen-induced retinopathy. Graefe's Arch. Clin. Exp. Ophthalmol. 2009, 247, 919-927. [CrossRef] 
41. Ristori, C.; Filippi, L.; Dal Monte, M.; Martini, D.; Cammalleri, M.; Fortunato, P.; la Marca, G.; Fiorini, P.; Bagnoli, P. Role of the adrenergic system in a mouse model of oxygen-induced retinopathy: Antiangiogenic effects of $\beta$-adrenoreceptor blockade. Investig. Ophthalmol. Vis. Sci. 2011, 52, 155-170. [CrossRef] [PubMed]

42. Monte, M.D.; Casini, G.; La Marca, G.; Isacchi, B.; Filippi, L.; Bagnoli, P. Eye drop propranolol administration promotes the recovery of oxygen-induced retinopathy in mice. Exp. Eye Res. 2013, 111, 27-35. [CrossRef] [PubMed]

43. Martini, D.; Monte, M.D.; Ristori, C.; Cupisti, E.; Mei, S.; Fiorini, P.; Filippi, L.; Bagnoli, P. Antiangiogenic effects of $\beta 2$-adrenergic receptor blockade in a mouse model of oxygen-induced retinopathy. J. Neurochem. 2011, 119, 1317-1329. [CrossRef] [PubMed]

44. Rotschild, T.; Nandgaonkar, B.N.; Yu, K.; Higgins, R.D. Dexamethasone Reduces Oxygen Induced Retinopathy in a Mouse Model. Pediatr. Res. 1999, 46, 94-100. [CrossRef] [PubMed]

45. Penn, J.S.; Rajaratnam, V.S.; Collier, R.J.; Clark, A.F. The effect of an angiostatic steroid on neovascularization in a rat model of retinopathy of prematurity. Investig. Ophthalmol. Vis. Sci. 2001, 42, 283-290.

46. Kim, J.H.; Yu, Y.S.; Shin, J.Y.; Lee, H.-Y.; Kim, K.-W. Deguelin inhibits retinal neovascularization by down-regulation of HIF-1 $\alpha$ in oxygen-induced retinopathy. J. Cell. Mol. Med. 2008, 12, 2407-2415. [CrossRef]

47. DeNiro, M.; Al-Halafi, A.; Al-Mohanna, F.H.; AlSmadi, O.; Al-Mohanna, F.A. Pleiotropic effects of YC-1 selectively inhibit pathological retinal neovascularization and promote physiological revascularization in a mouse model of oxygen-induced retinopathy. Mol. Pharmacol. 2010, 77, 348-367. [CrossRef]

48. Park, S.W.; Kim, J.H.; Kim, K.E.; Jeong, M.H.; Park, H.; Park, B.; Suh, Y.G.; Park, W.J.; Kim, J.H. Beta-lapachone inhibits pathological retinal neovascularization in oxygen-induced retinopathy via regulation of HIF-1 $\alpha$. J. Cell. Mol. Med. 2014, 18, 875-884. [CrossRef]

49. Pan, H.; Nguyen, N.-Q.-N.; Yoshida, H.; Bentzien, F.; Shaw, L.C.; Rentier-Delrue, F.; Martial, J.A.; Weiner, R.; Struman, I.; Grant, M.B. Molecular targeting of antiangiogenic factor 16K hPRL inhibits oxygen-induced retinopathy in mice. Investig. Opthalmol. Vis. Sci. 2004, 45, 2413-2419. [CrossRef]

50. Al-Shabrawey, M.; Mussell, R.; Kahook, K.; Tawfik, A.; Eladl, M.; Sarthy, V.; Nussbaum, J.; El-Marakby, A.; Park, S.Y.; Gurel, Z. Increased expression and activity of 12-lipoxygenase in oxygen-induced ischemic retinopathy and proliferative diabetic retinopathy: Implications in retinal neovascularization. Diabetes 2011, 60, 614-624. [CrossRef]

51. Liang, X.; Zhou, H.; Ding, Y.; Li, J.; Yang, C.; Luo, Y.; Li, S.; Sun, G.; Liao, X.; Min, W. TMP Prevents Retinal Neovascularization and Imparts Neuroprotection in an Oxygen-Induced Retinopathy Model. Investig. Opthalmol. Vis. Sci. 2012, 53, 2157-2169. [CrossRef] [PubMed]

52. Zhang, S.X.; Sima, J.; Shao, C.; Fant, J.; Chen, Y.; Rohrer, B.; Gao, G.; Ma, J.-X. Plasminogen kringle 5 reduces vascular leakage in the retina in rat models of oxygen-induced retinopathy and diabetes. Diabetologia 2004, 47, 124-131. [CrossRef]

53. Xu, Z.; Gong, J.; Maiti, D.; Vong, L.; Wu, L.; Schwarz, J.J.; Duh, E.J. MEF2C Ablation in Endothelial Cells Reduces Retinal Vessel Loss and Suppresses Pathologic Retinal Neovascularization in Oxygen-Induced Retinopathy. Am. J. Pathol. 2012, 180, 2548-2560. [CrossRef]

54. Ferrara, N.; Davis-Smyth, T. The Biology of Vascular Endothelial Growth Factor. Endocr. Rev. 1997, 18, 4-25. [CrossRef]

55. Ferrara, N.; Gerber, H.P. Vascular endothelial growth factor molecular and biological aspects. In Advances in Organ Biology; Elsevier: Amsterdam, The Netherlands, 1999; pp. 25-57.

56. Cavallaro, G.; Filippi, L.; Bagnoli, P.; La Marca, G.; Cristofori, G.; Raffaeli, G.; Padrini, L.; Araimo, G.; Fumagalli, M.; Groppo, M.; et al. The pathophysiology of retinopathy of prematurity: An update of previous and recent knowledge. Acta Ophthalmol. 2014, 92, 2-20. [CrossRef] [PubMed]

57. Abbracchio, M.; Brambilla, R.; Ceruti, S.; Kim, H.; Von Lubitz, D.; Jacobson, K.; Cattabeni, F. G-protein-dependent activation of phospholipase $\mathrm{C}$ by adenosine A3 receptors in rat brain. Pharmacol. Res. 1995, 31, 168. [CrossRef]

58. Bellik, L.; Vinci, M.C.; Filippi, S.; Ledda, F.; Parenti, A. Intracellular pathways triggered by the selective FLT-1-agonist placental growth factor in vascular smooth muscle cells exposed to hypoxia. Br. J. Pharmacol. 2005, 146, 568-575. [CrossRef] [PubMed]

59. Terman, B.I.; Dougher-Vermazen, M.; Carrion, M.E.; Dimitrov, D.; Armellino, D.C.; Gospodarowicz, D.; Böhlen, P. Identification of the KDR tyrosine kinase as a receptor for vascular endothelial cell growth factor. Biochem. Biophys. Res. Commun. 1992, 187, 1579-1586. [CrossRef] 
60. Quinn, T.P.; Peters, K.G.; De Vries, C.; Ferrara, N.; Williams, L.T. Fetal liver kinase 1 is a receptor for vascular endothelial growth factor and is selectively expressed in vascular endothelium. Proc. Natl. Acad. Sci. USA 1993, 90, 7533-7537. [CrossRef] [PubMed]

61. Waltenberger, J.; Claesson-Welsh, L.; Siegbahn, A.; Shibuya, M.; Heldin, C.H. Different signal transduction properties of KDR and Flt1, two receptors for vascular endothelial growth factor. J. Boil. Chem. 1994, 269, 26988-26995.

62. Bernatchez, P.N.; Soker, S.; Sirois, M.G. Vascular Endothelial Growth Factor Effect on Endothelial Cell Proliferation, Migration, and Platelet-activating Factor Synthesis Is Flk-1-dependent. J. Boil. Chem. 1999, 274, 31047-31054. [CrossRef] [PubMed]

63. Kaur, C.; Foulds, W.; Ling, E. Blood-retinal barrier in hypoxic ischaemic conditions: Basic concepts, clinical features and management. Prog. Retin. Eye Res. 2008, 27, 622-647. [CrossRef] [PubMed]

64. Provis, J. Development of the Primate Retinal Vasculature. Prog. Retin. Eye Res. 2001, 20, 799-821. [CrossRef]

65. Gariano, R.F.; Gardner, T.W. Retinal angiogenesis in development and disease. Nature 2005, 438, 960-966. [CrossRef] [PubMed]

66. Stone, J.; Maslim, J. Mechanisms of retinal angiogenesis. Prog. Retin. Eye Res. 1997, 16, 157-181. [CrossRef]

67. Hellström, A. IGF-I Is Critical for Normal Vascularization of the Human Retina. J. Clin. Endocrinol. Metab. 2002, 87, 3413-3416. [CrossRef] [PubMed]

68. Hellström, A.; Perruzzi, C.; Ju, M.; Engström, E.; Hård, A.-L.; Liu, J.-L.; Albertsson-Wikland, K.; Carlsson, B.; Niklasson, A.; Sjödell, L.; et al. Low IGF-I suppresses VEGF-survival signaling in retinal endothelial cells: Direct correlation with clinical retinopathy of prematurity. Proc. Natl. Acad. Sci. USA 2001, 98, 5804-5808. [CrossRef] [PubMed]

69. Yamaji, R.; Okada, T.; Moriya, M.; Naito, M.; Tsuruo, T.; Miyatake, K.; Nakano, Y. Brain Capillary Endothelial Cells Express two forms of Erythropoietin Receptor mRNA. JBIC J. Boil. Inorg. Chem. 1996, 239, 494-500. [CrossRef] [PubMed]

70. Watts, K.D.; McColley, S.A. Elevated vascular endothelial growth factor is correlated with elevated erythropoietin in stable, young cystic fibrosis patients. Pediatr. Pulmonol. 2011, 46, 683-687. [CrossRef] [PubMed]

71. Chen, J.; Connor, K.M.; Aderman, C.M.; Smith, L.E. Erythropoietin deficiency decreases vascular stability in mice. J. Clin. Investig. 2008, 118, 526-533. [CrossRef] [PubMed]

72. Hartnett, M.E. Pathophysiology and mechanisms of severe retinopathy of prematurity. Ophthalmology 2015, 122, 200-210. [CrossRef] [PubMed]

73. Rusai, K.; Vannay, A.; Szebeni, B.; Borgulya, G.; Fekete, A.; Vásárhelyi, B.; Tulassay, T.; Szabó, A.J. Endothelial nitric oxide synthase gene $\mathrm{T}-786 \mathrm{C}$ and $27-\mathrm{bp}$ repeat gene polymorphisms in retinopathy of prematurity. Mol. Vis. 2008, 14, 286-290. [PubMed]

74. Yanamandra, K.; Napper, D.; Pramanik, A.; Bocchini, J.A.; Dhanireddy, R. Endothelial Nitric Oxide Synthase genotypes in the etiology of retinopathy of prematurity in premature infants. Ophthalmic Genet. 2010, 31, 173-177. [CrossRef] [PubMed]

75. Hashiguchi, A.; Yano, S.; Morioka, M.; Hamada, J.; Ushio, Y.; Takeuchi, Y.; Fukunaga, K. Up-Regulation of Endothelial Nitric Oxide Synthase via Phosphatidylinositol 3-Kinase Pathway Contributes to Ischemic Tolerance in the CA1 Subfield of Gerbil Hippocampus. Br. J. Pharmacol. 2004, 24, 271-279. [CrossRef] [PubMed]

76. Haskó, G.; Cronstein, B.N. Regulation of Inflammation by Adenosine. Front. Immunol. 2013, 4, 85. [CrossRef] [PubMed]

77. Madeira, M.H.; Boia, R.; Elvas, F.; Martins, T.; Cunha, R.A.; Ambrósio, A.F.; Santiago, A.R.; Information, P.E.K.F.C. Selective A2A receptor antagonist prevents microglia-mediated neuroinflammation and protects retinal ganglion cells from high intraocular pressure-induced transient ischemic injury. Transl. Res. 2016, 169, 112-128. [CrossRef]

78. Cerri, S.; Levandis, G.; Ambrosi, G.; Montepeloso, E.; Antoninetti, G.F.; Franco, R.; Lanciego, J.L.; Baqi, Y.; Müller, C.E.; Pinna, A. Neuroprotective potential of adenosine A2A and cannabinoid CB1 receptor antagonists in an animal model of Parkinson disease. J. Neuropathol. Exp. Neurol. 2014, 73, 414-424. [CrossRef]

79. Gyoneva, S.; Shapiro, L.; Lazo, C.; Garnier-Amblard, E.; Smith, Y.; Miller, G.W.; Traynelis, S.F. Adenosine A2A receptor antagonism reverses inflammation-induced impairment of microglial process extension in a model of Parkinson's disease. Neurobiol. Dis. 2014, 67, 191-202. [CrossRef] 
80. Canas, P.M.; Porciúncula, L.O.; Cunha, G.M.A.; Silva, C.G.; Machado, N.J.; Oliveira, J.M.A.; Oliveira, C.R.; Cunha, R.A. Adenosine A2A Receptor Blockade Prevents Synaptotoxicity and Memory Dysfunction Caused by $\beta$-Amyloid Peptides via p38 Mitogen-Activated Protein Kinase Pathway. J. Neurosci. 2009, 29, 14741-14751. [CrossRef]

81. Chen, J.F.; Huang, Z.; Ma, J.; Zhu, J.; Moratalla, R.; Standaert, D.; Moskowitz, M.A.; Fink, J.S.; Schwarzschild, M.A. A2A adenosine receptor deficiency attenuates brain injury induced by transient focal ischemia in mice. J. Neurosci. 1999, 19, 9192-9200. [CrossRef]

82. Santiago, A.R.; Baptista, F.I.; Santos, P.F.; Cristóvão, G.; Ambrósio, A.F.; Cunha, R.A.; Gomes, C.A. Role of microglia adenosine A2A receptors in retinal and brain neurodegenerative diseases. Mediat. Inflamm. 2014, 2014, 465694. [CrossRef]

83. Fischer, S.; Sharma, H.; Karliczek, G.; Schaper, W. Expression of vascular permeability factor/vascular endothelial growth factor in pig cerebral microvascular endothelial cells and its upregulation by adenosine. Mol. Brain Res. 1995, 28, 141-148. [CrossRef]

84. Takagi, H.; King, G.L.; Ferrara, N.; Aiello, L.P. Hypoxia regulates vascular endothelial growth factor receptor KDR/Flk gene expression through adenosine A2 receptors in retinal capillary endothelial cells. Investig. Ophthalmol. Vis. Sci. 1996, 37, 1311-1321.

85. Grant, M.B.; Davis, M.I.; Caballero, S.; Feoktistov, I.; Biaggioni, I.; Belardinelli, L. Proliferation, migration, and ERK activation in human retinal endothelial cells through A2B adenosine receptor stimulation. Investig. Ophthalmol. Vis. Sci. 2001, 42, 2068-2073.

86. De Hoz, R.; Gallego, B.I.; Ramírez, A.I.; Rojas, B.; Salazar, J.J.; Valiente-Soriano, F.J.; Avilés-Trigueros, M.; Villegas-Perez, M.P.; Vidal-Sanz, M.; Triviño, A. Rod-like microglia are restricted to eyes with laser-induced ocular hypertension but absent from the microglial changes in the contralateral untreated eye. PLoS ONE 2013, 8, e83733. [CrossRef] [PubMed]

87. Taylor, S.; Calder, C.J.; Albon, J.; Erichsen, J.T.; Boulton, M.E.; Morgan, J.E. Involvement of the CD200 receptor complex in microglia activation in experimental glaucoma. Exp. Eye Res. 2011, 92, 338-343. [CrossRef] [PubMed]

88. Smith, C.P.; Sharma, S.; Steinle, J.J. Age-related changes in sympathetic neurotransmission in rat retina and choroid. Exp. Eye Res. 2007, 84, 75-81. [CrossRef]

89. Steinle, J.J.; Smith, P.G. Role of adrenergic receptors in vascular remodelling of the rat choroid. Br. J. Pharmacol. 2002, 136, 730-734. [CrossRef] [PubMed]

90. Guimarães, S.; Moura, D. Vascular adrenoceptors: An update. Pharmacol. Rev. 2001, 53, 319-356.

91. Smith, L.; Wesolowski, E.; McLellan, A.; Kostyk, S.K.; D'Amato, R.; Sullivan, R.; D'Amore, P.A. Oxygen-induced retinopathy in the mouse. Investig. Ophthalmol. Vis. Sci. 1994, 35, 101-111.

92. Grossniklaus, H.E.; Kang, S.J.; Berglin, L. Animal Models of Choroidal and Retinal Neovascularization. Prog. Retin. Eye Res. 2010, 29, 500-519. [CrossRef] [PubMed]

93. Penn, J.S.; Tolman, B.L.; Lowery, L.A. Variable oxygen exposure causes preretinal neovascularization in the newborn rat. Investig. Ophthalmol. Vis. Sci. 1993, 34, 576-585.

94. Rapisarda, A.; Uranchimeg, B.; Sordet, O.; Pommier, Y.; Shoemaker, R.H.; Melillo, G. Topoisomerase I-mediated inhibition of hypoxia-inducible factor 1: Mechanism and therapeutic implications. Cancer Res. 2004, 64, 1475-1482. [CrossRef] [PubMed]

95. Yu, T.; Tang, B.; Sun, X. Development of Inhibitors Targeting Hypoxia-Inducible Factor 1 and 2 for Cancer Therapy. Yonsei Med. J. 2017, 58, 489-496. [CrossRef] [PubMed]

96. Miwa, Y.; Hoshino, Y.; Shoda, C.; Jiang, X.; Tsubota, K.; Kurihara, T. Pharmacological HIF inhibition prevents retinal neovascularization with improved visual function in a murine oxygen-induced retinopathy model. Neurochem. Int. 2019, 128, 21-31. [CrossRef] [PubMed]

97. Chen, J.; Joyal, J.-S.; Hatton, C.J.; Juan, A.M.; Pei, D.T.; Hurst, C.G.; Xu, D.; Stahl, A.; Hellström, A.; Smith, L.E.H. Propranolol Inhibition of $\beta$-Adrenergic Receptor Does Not Suppress Pathologic Neovascularization in Oxygen-Induced Retinopathy. Investig. Opthalmol. Vis. Sci. 2012, 53, 2968-2977. [CrossRef] [PubMed]

98. Yun, J.-H.; Koh, Y.J.; Jeong, H.-S.; Lee, D.-H.; Lee, E.H.; Cho, C.-H. Propranolol increases vascular permeability through pericyte apoptosis and exacerbates oxygen-induced retinopathy. Biochem. Biophys. Res. Commun. 2018, 503, 2792-2799. [CrossRef] [PubMed] 
99. Parupia, M.H.; Dhanireddy, R. Association of Postnatal Dexamethasone Use and Fungal Sepsis in the Development of Severe Retinopathy of Prematurity and Progression to Laser Therapy in Extremely Low-Birth-Weight Infants. J. Perinatol. 2001, 21, 242-247. [CrossRef]

100. Pisani, F.; Cammalleri, M.; Dal Monte, M.; Locri, F.; Mola, M.G.; Nicchia, G.P.; Frigeri, A.; Bagnoli, P.; Svelto, M. Potential role of the methylation of VEGF gene promoter in response to hypoxia in oxygen-induced retinopathy: Beneficial effect of the absence of AQP4. J. Cell. Mol. Med. 2018, 22, 613-627. [CrossRef]

101. Kolibabka, M.; Dietrich, N.; Klein, T.; Hammes, H.-P. Anti-angiogenic effects of the DPP-4 inhibitor linagliptin via inhibition of VEGFR signalling in the mouse model of oxygen-induced retinopathy. Diabetologia 2018, 61, 2412-2421. [CrossRef]

102. Vähätupa, M.; Cordova, Z.M.; Barker, H.; Aittomäki, S.; Uusitalo, H.; Järvinen, T.A.; Pesu, M.; Uusitalo-Järvinen, H. Furin deficiency in myeloid cells leads to attenuated revascularization in a mouse-model of oxygen-induced retinopathy. Exp. Eye Res. 2018, 166, 160-167. [CrossRef] [PubMed]

103. Lu, C.-S.; Lee, Y.-N.; Wang, S.-W.; Wu, Y.-J.; Su, C.-H.; Hsieh, C.-L.; Tien, T.Y.; Wang, B.-J.; Chen, M.-C.; Chen, C.-W.; et al. KC21 Peptide Inhibits Angiogenesis and Attenuates Hypoxia-Induced Retinopathy. J. Cardiovasc. Transl. Res. 2019, 12, 366-377. [CrossRef] [PubMed]

104. Tang, F.; Leblanc, M.E.; Wang, W.; Liang, D.; Chen, P.; Chou, T.-H.; Tian, H.; Li, W. Anti-secretogranin III therapy of oxygen-induced retinopathy with optimal safety. Angiogenesis 2019, 22, 369-382. [CrossRef] [PubMed]

105. Geng, W.; Qin, F.; Ren, J.; Xiao, S.; Wang, A. Mini-peptide RPL41 attenuated retinal neovascularization by inducing degradation of ATF4 in oxygen-induced retinopathy mice. Exp. Cell Res. 2018, 369, 243-250. [CrossRef] [PubMed]

106. Iizuka, N.; Morita, A.; Kawano, C.; Mori, A.; Sakamoto, K.; Kuroyama, M.; Ishii, K.; Nakahara, T. Anti-angiogenic effects of valproic acid in a mouse model of oxygen-induced retinopathy. J. Pharmacol. Sci. 2018, 138, 203-208. [CrossRef] [PubMed]

107. Lalkovičová, M.; Danielisová, V. Neuroprotection and antioxidants. Neural Regen. Res. 2016, 11, 865. [CrossRef] [PubMed]

108. Sohn, E.H.; Van Dijk, H.W.; Jiao, C.; Kok, P.H.B.; Jeong, W.; Demirkaya, N.; Garmager, A.; Wit, F.; Kucukevcilioglu, M.; Van Velthoven, M.E.J.; et al. Retinal neurodegeneration may precede microvascular changes characteristic of diabetic retinopathy in diabetes mellitus. Proc. Natl. Acad. Sci. USA 2016, 113, E2655-E2664. [CrossRef] [PubMed]

109. Chen, Y.; Hu, Y.; Zhou, T.; Zhou, K.K.; Mott, R.; Wu, M.; Boulton, M.; Lyons, T.J.; Gao, G.; Ma, J.-X. Activation of the Wnt Pathway Plays a Pathogenic Role in Diabetic Retinopathy in Humans and Animal Models. Am. J. Pathol. 2009, 175, 2676-2685. [CrossRef]

110. Simó, R.; Carrasco, E.; García-Ramírez, M.; Hernández, C. Angiogenic and antiangiogenic factors in proliferative diabetic retinopathy. Curr. Diabetes Rev. 2006, 2, 71-98. [CrossRef]

111. Vessey, K.; Wilkinson-Berka, J.; Fletcher, E. Characterization of retinal function and glial cell response in a mouse model of oxygen-induced retinopathy. J. Comp. Neurol. 2011, 519, 506-527. [CrossRef]

112. Obrosova, I.G. Increased Sorbitol Pathway Activity Generates Oxidative Stress in Tissue Sites for Diabetic Complications. Antioxid. Redox Signal. 2005, 7, 1543-1552. [CrossRef] [PubMed]

113. Meneses, P.; Hajjar, K.; Berns, K.; Duvoisin, R. Recombinant angiostatin prevents retinal neovascularization in a murine proliferative retinopathy model. Gene Ther. 2001, 8, 646. [CrossRef] [PubMed]

114. Kermorvant-Duchemin, E.; Sapieha, P.; Sirinyan, M.; Beauchamp, M.; Checchin, D.; Hardy, P.; Sennlaub, F.; Lachapelle, P.; Chemtob, S. Understanding ischemic retinopathies: Emerging concepts from oxygen-induced retinopathy. Doc. Ophthalmol. 2010, 120, 51-60. [CrossRef] [PubMed]

115. Wang, M.; Tsao, R.; Zhang, S.; Dong, Z.; Yang, R.; Gong, J.; Pei, Y. Antioxidant activity, mutagenicity/anti-mutagenicity, and clastogenicity/anti-clastogenicity of lutein from marigold flowers. Food Chem. Toxicol. 2006, 44, 1522-1529. [CrossRef] [PubMed]

116. Maoka, T.; Tokuda, H.; Suzuki, N.; Kato, H.; Etoh, H. Anti-Oxidative, Anti-Tumor-Promoting, and Anti-Carcinogensis Activities of Nitroastaxanthin and Nitrolutein, the Reaction Products of Astaxanthin and Lutein with Peroxynitrite. Mar. Drugs 2012, 10, 1391-1399. [CrossRef] [PubMed]

117. Li, S.-Y.; Fu, Z.-J.; Ma, H.; Jang, W.-C.; So, K.-F.; Wong, D.; Lo, A.C.Y. Effect of Lutein on Retinal Neurons and Oxidative Stress in a Model of Acute Retinal Ischemia/Reperfusion. Investig. Opthalmol. Vis. Sci. 2009, 50, 836-843. [CrossRef] [PubMed] 
118. Li, S.-Y.; Yang, D.; Fu, Z.J.; Woo, T.; Wong, D.; Lo, A.C.Y. Lutein enhances survival and reduces neuronal damage in a mouse model of ischemic stroke. Neurobiol. Dis. 2012, 45, 624-632. [CrossRef] [PubMed]

119. Sasaki, M.; Ozawa, Y.; Kurihara, T.; Noda, K.; Imamura, Y.; Kobayashi, S.; Ishida, S.; Tsubota, K. Neuroprotective Effect of an Antioxidant, Lutein, during Retinal Inflammation. Investig. Opthalmol. Vis. Sci. 2009, 50, 1433-1439. [CrossRef] [PubMed]

120. Alves-Rodrigues, A.; Shao, A. The science behind lutein. Toxicol. Lett. 2004, 150, 57-83. [CrossRef] [PubMed]

121. Snodderly, D.M. Evidence for protection against age-related macular degeneration by carotenoids and antioxidant vitamins. Am. J. Clin. Nutr. 1995, 62, 1448S-1461S. [CrossRef]

122. Bone, R.A.; Landrum, J.T.; Friedes, L.M.; Gomez, C.M.; Kilburn, M.D.; Menendez, E.; Vidal, I.; Wang, W. Distribution of Lutein and Zeaxanthin Stereoisomers in the Human Retina. Exp. Eye Res. 1997, 64, 211-218. [CrossRef] [PubMed]

123. Sommerburg, O.; Keunen, J.E.E.; Bird, A.C.; Van Kuijk, F.J.G.M. Fruits and vegetables that are sources for lutein and zeaxanthin: The macular pigment in human eyes. Br. J. Ophthalmol. 1998, 82, 907-910. [CrossRef] [PubMed]

124. Fung, F.K.C.; Wong, D.; Chan, H.H.L.; Lo, A.C.Y.; Li, S.-Y.; Fu, Z.J. Anti-Inflammatory Effects of Lutein in Retinal Ischemic/Hypoxic Injury: In Vivo and In Vitro Studies. Investig. Opthalmol. Vis. Sci. 2012, 53, 5976-5984.

125. Li, S.-Y.; Lo, A.C.Y. Lutein Protects RGC-5 Cells Against Hypoxia and Oxidative Stress. Int. J. Mol. Sci. 2010, 11, 2109-2117. [CrossRef] [PubMed]

126. Woo, T.T.; Li, S.-Y.; Lai, W.W.; Wong, D.; Lo, A.C. Neuroprotective effects of lutein in a rat model of retinal detachment. Graefe's Archive for Clin. Exp. Ophthalmol. 2013, 251, 41-51. [CrossRef]

127. Zhang, C.; Wang, Z.; Zhao, J.; Li, Q.; Huang, C.; Zhu, L.; Lu, D. Neuroprotective effect of lutein on NMDA-induced retinal ganglion cell injury in rat retina. Cell. Mol. Neurobiol. 2016, 36, 531-540. [CrossRef]

128. Fu, Z.; Meng, S.S.; Burnim, S.B.; Smith, L.E.; Lo, A.C. Lutein facilitates physiological revascularization in a mouse model of retinopathy of prematurity. Clin. Exp. Ophthalmol. 2017, 45, 529-538. [CrossRef]

129. Shi, X.; Dalal, N.; Jain, A. Antioxidant behaviour of caffeine: Efficient scavenging of hydroxyl radicals. Food Chem. Toxicol. 1991, 29, 1-6. [CrossRef]

130. Barcelos, R.P.; Souza, M.A.; Amaral, G.P.; Stefanello, S.T.; Bresciani, G.; Fighera, M.R.; Soares, F.A.A.; Barbosa, N.V. Caffeine supplementation modulates oxidative stress markers in the liver of trained rats. Life Sci. 2014, 96, 40-45. [CrossRef]

131. Devasagayam, T.; Kamat, J.; Mohan, H.; Kesavan, P. Caffeine as an antioxidant: Inhibition of lipid peroxidation induced by reactive oxygen species. Biochim. Biophys. Acta (BBA) Biomembr. 1996, 1282, 63-70. [CrossRef]

132. Chavez-Valdez, R.; Wills-Karp, M.; Ahlawat, R.; Cristofalo, E.A.; Nathan, A.; Gauda, E.B. Caffeine Modulates TNF- $\alpha$ Production by Cord Blood Monocytes: The Role of Adenosine Receptors. Pediatr. Res. 2009, 65, 203-208. [CrossRef] [PubMed]

133. Li, J.; Li, G.; Hu, J.-L.; Fu, X.-H.; Zeng, Y.-J.; Zhou, Y.-G.; Xiong, G.; Yang, N.; Dai, S.-S.; He, F.-T. Chronic or high dose acute caffeine treatment protects mice against oleic acid-induced acute lung injury via an adenosine A2A receptor-independent mechanism. Eur. J. Pharmacol. 2011, 654, 295-303. [CrossRef] [PubMed]

134. Dall'Lgna, O.P.; Porciúncula, L.O.; Souza, D.O.; Cunha, R.A.; Lara, D.R. Neuroprotection by caffeine and adenosine A2A receptor blockade of $\beta$-amyloid neurotoxicity. Br. J. Pharmacol. 2003, 138, 1207-1209. [CrossRef] [PubMed]

135. Endesfelder, S.; Zaak, I.; Weichelt, U.; Bührer, C.; Schmitz, T. Caffeine protects neuronal cells against injury caused by hyperoxia in the immature brain. Free. Radic. Boil. Med. 2014, 67, 221-234. [CrossRef] [PubMed]

136. Zhang, S.; Zhou, R.; Li, B.; Li, H.; Wang, Y.; Gu, X.; Tang, L.; Wang, C.; Zhong, D.; Ge, Y.; et al. Caffeine preferentially protects against oxygen-induced retinopathy. FASEB J. 2017, 31, 3334-3348. [CrossRef] [PubMed]

137. Barberger-Gateau, P.; Letenneur, L.; Deschamps, V.; Pérès, K.; Dartigues, J.-F.; Renaud, S. Fish, meat, and risk of dementia: Cohort study. BMJ 2002, 325, 932-933. [CrossRef]

138. Morris, M.C.; Evans, D.A.; Bienias, J.L.; Tangney, C.C.; Bennett, D.A.; Wilson, R.S.; Aggarwal, N.; Schneider, J. Consumption of Fish and n-3 Fatty Acids and Risk of Incident Alzheimer Disease. Arch. Neurol. 2003, 60, 940-946. [CrossRef] [PubMed] 
139. Calon, F.; Cole, G. Neuroprotective action of omega-3 polyunsaturated fatty acids against neurodegenerative diseases: Evidence from animal studies. Prostaglandins Leukot. Essent. Fat. Acids 2007, 77, 287-293. [CrossRef] [PubMed]

140. Calon, F.; Lim, G.P.; Yang, F.; Morihara, T.; Teter, B.; Ubeda, O.; Rostaing, P.; Triller, A.; Salem, N.; Ashe, K.H.; et al. Docosahexaenoic Acid Protects from Dendritic Pathology in an Alzheimer's Disease Mouse Model. Neuron 2004, 43, 633-645. [CrossRef]

141. Shimazawa, M.; Nakajima, Y.; Mashima, Y.; Hara, H. Docosahexaenoic acid (DHA) has neuroprotective effects against oxidative stress in retinal ganglion cells. Brain Res. 2009, 1251, 269-275. [CrossRef]

142. Sapieha, P.; Stahl, A.; Chen, J.; Seaward, M.R.; Willett, K.L.; Krah, N.M.; Dennison, R.J.; Connor, K.M.; Aderman, C.M.; Liclican, E.; et al. 5-Lipoxygenase Metabolite 4-HDHA Is a Mediator of the Antiangiogenic Effect of $\omega$-3 Polyunsaturated Fatty Acids. Sci. Transl. Med. 2011, 3, 69ra12. [CrossRef] [PubMed]

143. Stahl, A.; Sapieha, P.; Connor, K.M.; SanGiovanni, J.P.; Chen, J.; Aderman, C.M.; Willett, K.L.; Krah, N.M.; Dennison, R.J.; Seaward, M.R.; et al. PPAR $\gamma$ mediates a direct anti-angiogenic effect of $\omega 3-P U F A s$ in proliferative retinopathy. Circ. Res. 2010, 107, 495-500. [CrossRef] [PubMed]

144. Beharry, K.D.; Cai, C.L.; Siddiqui, F.; Chowdhury, S.; D’Agrosa, C.; Valencia, G.B.; Aranda, J.V. Comparative Effects of Coenzyme Q10 or n-3 Polyunsaturated Fatty Acid Supplementation on Retinal Angiogenesis in a Rat Model of Oxygen-Induced Retinopathy. Antioxidants 2018, 7, 160. [CrossRef] [PubMed]

145. De La Lastra, C.A.; Villegas, I. Resveratrol as an antioxidant and pro-oxidant agent: Mechanisms and clinical implications. Biochem. Soc. Trans. 2007, 35, 1156-1160. [CrossRef] [PubMed]

146. Zini, R.; Morin, C.; Bertelli, A.A.; Tillement, J.P. Effects of resveratrol on the rat brain respiratory chain. Drugs Under Exp. Clin. Res. 1999, 25, 87-97.

147. Sinha, K.; Chaudhary, G.; Gupta, Y.K. Protective effect of resveratrol against oxidative stress in middle cerebral artery occlusion model of stroke in rats. Life Sci. 2002, 71, 655-665. [CrossRef]

148. Martín, A.R.; Villegas, I.; La Casa, C.; de la Lastra, C.A. Resveratrol, a polyphenol found in grapes, suppresses oxidative damage and stimulates apoptosis during early colonic inflammation in rats. Biochem. Pharmacol. 2004, 67, 1399-1410. [PubMed]

149. Martín, A.R.; Villegas, I.; Sánchez-Hidalgo, M.; De La Lastra, C.A. The effects of resveratrol, a phytoalexin derived from red wines, on chronic inflammation induced in an experimentally induced colitis model. Br. J. Pharmacol. 2006, 147, 873-885. [CrossRef]

150. Jin, F.; Wu, Q.; Lu, Y.-F.; Gong, Q.-H.; Shi, J.-S. Neuroprotective effect of resveratrol on 6-OHDA-induced Parkinson's disease in rats. Eur. J. Pharmacol. 2008, 600, 78-82. [CrossRef]

151. Ates, O.; Cayli, S.; Altinoz, E.; Gurses, I.; Yucel, N.; Sener, M.; Kocak, A.; Yologlu, S. Neuroprotection by resveratrol against traumatic brain injury in rats. Mol. Cell. Biochem. 2007, 294, 137-144. [CrossRef]

152. Lopez, M.S.; Dempsey, R.J.; Vemuganti, R. Resveratrol neuroprotection in stroke and traumatic CNS injury. Neurochem. Int. 2015, 89, 75-82. [CrossRef] [PubMed]

153. Li, F.; Gong, Q.; Dong, H.; Shi, J. Resveratrol, a neuroprotective supplement for Alzheimer's disease. Curr. Pharm. Des. 2012, 18, 27-33. [CrossRef] [PubMed]

154. Bastianetto, S.; Ménard, C.; Quirion, R. Neuroprotective action of resveratrol. Biochim. Biophys. Acta (BBA) Mol. Basis Dis. 2015, 1852, 1195-1201. [CrossRef] [PubMed]

155. Lançon, A.; Frazzi, R.; Latruffe, N. Anti-Oxidant, Anti-Inflammatory and Anti-Angiogenic Properties of Resveratrol in Ocular Diseases. Molecules 2016, 21, 304. [CrossRef] [PubMed]

156. Kim, W.T.; Suh, E.S. Retinal Protective Effects of Resveratrol via Modulation of Nitric Oxide Synthase on Oxygen-induced Retinopathy. Korean J. Ophthalmol. 2010, 24, 108-118. [CrossRef] [PubMed]

157. Li, W.; Jiang, D. Effect of resveratrol on Bcl-2 and VEGF expression in oxygen-induced retinopathy of prematurity. J. Pediatr. Ophthalmol. Strabismus 2012, 49, 230-235. [CrossRef] [PubMed]

158. Akama, K.T.; Albanese, C.; Pestell, R.G.; Van Eldik, L.J. Amyloid $\beta$-peptide stimulates nitric oxide production in astrocytes through an NFkB-dependent mechanism. Proc. Natl. Acad. Sci. USA 1998, 95, 5795-5800. [CrossRef]

159. Sano, M.; Ernesto, C.; Thomas, R.G.; Klauber, M.R.; Schafer, K.; Grundman, M.; Woodbury, P.; Growdon, J.; Cotman, C.W.; Pfeiffer, E. A controlled trial of selegiline, alpha-tocopherol, or both as treatment for Alzheimer's disease. N. Engl. J. Med. 1997, 336, 1216-1222. [CrossRef] 
160. Penn, J.S.; Tolman, B.L.; Bullard, L.E. Effect of a Water-Soluble Vitamin E Analog, Trolox C, on Retinal Vascular Development in an Animal Model of Retinopathy of Prematurity. Free. Radic. Boil. Med. 1997, 22, 977-984. [CrossRef]

161. Penn, J.S.; Thum, L.A.; Naash, M.I. Oxygen-induced retinopathy in the rat. Vitamins C and E as potential therapies. Investig. Ophthalmol. Vis. Sci. 1992, 33, 1836-1845.

162. Johnson, L.; Quinn, G.E.; Abbasi, S.; Otis, C.; Goldstein, D.; Sacks, L.; Porat, R.; Fong, E.; Delivoria-Papadopoulos, M.; Peckham, G.; et al. Effect of sustained pharmacologic vitamin E levels on incidence and severity of retinopathy of prematurity: A controlled clinical trial. J. Pediatr. 1989, 114, 827-838. [CrossRef]

163. Raju, T.N.; Langenberg, P.; Bhutani, V.; Quinn, G.E. Vitamin E prophylaxis to reduce retinopathy of prematurity: A reappraisal of published trials. J. Pediatr. 1997, 131, 844-850. [CrossRef]

164. Finer, N.N.; Schindler, R.F.; Grant, G.; Hill, G.B.; Peters, K. Effect of intramuscular vitamin E on frequency and severity of retrolental fibroplasia. A controlled trial. Lancet 1982, 1, 1087-1091. [CrossRef]

165. Phelps, D.L.; Rosenbaum, A.L.; Isenberg, S.J.; Leake, R.D.; Dorey, F.J. Tocopherol efficacy and safety for preventing retinopathy of prematurity: A randomized, controlled, double-masked trial. Pediatrics 1987, 79, 489-500. [PubMed]

166. Obrosova, I.G.; Pacher, P.; Szabó, C.; Zsengeller, Z.; Hirooka, H.; Stevens, M.J.; Yorek, M.A. Aldose Reductase Inhibition Counteracts Oxidative-Nitrosative Stress and Poly(ADP-Ribose) Polymerase Activation in Tissue Sites for Diabetes Complications. Diabetes 2005, 54, 234-242. [CrossRef] [PubMed]

167. Chung, S.S.; Ho, E.C.; Lam, K.S. Contribution of Polyol Pathway to Diabetes-Induced Oxidative Stress. J. Am. Soc. Nephrol. 2003, 14, 233-236. [CrossRef]

168. Lee, A.Y.W.; Chung, S.S.M. Contributions of polyol pathway to oxidative stress in diabetic cataract. FASEB J. 1999, 13, 23-30. [CrossRef]

169. Lou, M.F.; Dickerson, J.E.; Garadi, R.; York, B.M. Glutathione depletion in the lens of galactosemic and diabetic rats. Exp. Eye Res. 1988, 46, 517-530. [CrossRef]

170. Song, Z.; Fu, D.T.; Chan, Y.-S.; Leung, S.; Chung, S.S.; Chung, S.K. Transgenic mice overexpressing aldose reductase in Schwann cells show more severe nerve conduction velocity deficit and oxidative stress under hyperglycemic stress. Mol. Cell. Neurosci. 2003, 23, 638-647. [CrossRef]

171. Cheung, A.K.; Lo, A.C.; So, K.F.; Chung, S.S.; Chung, S.K.; Lo, A.C.Y. Gene deletion and pharmacological inhibition of aldose reductase protect against retinal ischemic injury. Exp. Eye Res. 2007, 85, 608-616. [CrossRef]

172. Obrosova, I.G.; Minchenko, A.G.; Vasupuram, R.; White, L.; Abatan, O.I.; Kumagai, A.K.; Frank, R.N.; Stevens, M.J.; Minchenko, O. Aldose Reductase Inhibitor Fidarestat Prevents Retinal Oxidative Stress and Vascular Endothelial Growth Factor Overexpression in Streptozotocin-Diabetic Rats. Diabetes 2003, 52, 864-871. [CrossRef] [PubMed]

173. Cheung, A.K.; Fung, M.K.; Lo, A.C.; Lam, T.T.; So, K.F.; Chung, S.S.; Chung, S.K. Aldose reductase deficiency prevents diabetes-induced blood-retinal barrier breakdown, apoptosis, and glial reactivation in the retina of $\mathrm{db} / \mathrm{db}$ mice. Diabetes 2005, 54, 3119-3125. [CrossRef] [PubMed]

174. Thomas, T.; Rauscher, F.; Sanders, R.; Veltman, J.; Watkins, J.B. Effects of Aldose Reductase Inhibitors on Antioxidant Defense in Rat and Rabbit Liver. Toxicol. Sci. 2000, 53, 145-149. [CrossRef] [PubMed]

175. Fu, Z.J.; Li, S.-Y.; Kociok, N.; Wong, D.; Chung, S.K.; Lo, A.C.Y. Aldose Reductase Deficiency Reduced Vascular Changes in Neonatal Mouse Retina in Oxygen-Induced Retinopathy. Investig. Opthalmol. Vis. Sci. 2012, 53, 5698-5712. [CrossRef] [PubMed]

176. Fu, Z.; Nian, S.; Li, S.-Y.; Wong, D.; Chung, S.K.; Lo, A.C.Y. Deficiency of aldose reductase attenuates inner retinal neuronal changes in a mouse model of retinopathy of prematurity. Graefe's Arch. Clin. Exp. Ophthalmol. 2015, 253, 1503-1513. [CrossRef] [PubMed]

177. Shimizu, K.; Rajapakse, N.; Horiguchi, T.; Payne, R.; Busija, D.W. Neuroprotection against hypoxia-ischemia in neonatal rat brain by novel superoxide dismutase mimetics. Neurosci. Lett. 2003, 346, 41-44. [CrossRef]

178. Spierer, A.; Rabinowitz, R.; Pri-Chen, S.; Rosner, M. An increase in superoxide dismutase ameliorates oxygen-induced retinopathy in transgenic mice. Eye 2005, 19, 86. [CrossRef]

179. Huang, H.F.; Guo, F.; Cao, Y.Z.; Shi, W.; Xia, Q. Neuroprotection by Manganese Superoxide Dismutase (M n SOD) Mimics: Antioxidant Effect and Oxidative Stress Regulation in Acute Experimental Stroke. CNS Neurosci. Ther. 2012, 18, 811-818. [CrossRef] 
180. Niesman, M.R.; Johnson, K.A.; Penn, J.S. Therapeutic Effect of Liposomal Superoxide Dismutase in an Animal Model of Retinopathy of Prematurity. Neurochem. Res. 1997, 22, 597-605. [CrossRef]

181. Dohare, P.; Hyzinski-García, M.C.; Vipani, A.; Bowens, N.H.; Nalwalk, J.W.; Feustel, P.J.; Keller, R.W., Jr.; Jourd'Heuil, D.; Mongin, A.A. The neuroprotective properties of the superoxide dismutase mimetic tempol correlate with its ability to reduce pathological glutamate release in a rodent model of stroke. Free. Radic. Boil. Med. 2014, 77, 168-182. [CrossRef]

182. Paraskevas, K.I.; Tzovaras, A.S.; Briana, D.D.; Mikhailidis, D.P. Emerging indications for statins: A pluripotent family of agents with several potential applications. Curr. Pharm. Des. 2007, 13, 3622-3636. [CrossRef] [PubMed]

183. Bonetti, P.; Lerman, L.; Napoli, C. Statin effects beyond lipid lowering-Are they clinically relevant? Eur. Hear. J. 2003, 24, 225-248. [CrossRef]

184. Wood, W.G.; Eckert, G.P.; Igbavboa, U.; Müller, W.E. Statins and neuroprotection: a prescription to move the field forward. Ann. N. Y. Acad. Sci. 2010, 1199, 69-76. [CrossRef] [PubMed]

185. Sigurdsson, G.; Haraldsdottir, S.O.; Melberg, T.H.; Tikkanen, M.J.; Miettinen, T.E.; Kristianson, K.J. Simvastatin compared to fluvastatin in the reduction of serum lipids and apolipoproteins in patients with ischaemic heart disease and moderate hypercholesterolaemia. Acta Cardiol. 1998, 53, 7-14. [PubMed]

186. Johnson-Anuna, L.N.; Eckert, G.P.; Keller, J.H.; Igbavboa, U.; Franke, C.; Fechner, T.; Schubert-Zsilavecz, M.; Karas, M.; Müller, W.E.; Wood, W.G. Chronic administration of statins alters multiple gene expression patterns in mouse cerebral cortex. J. Pharmacol. Exp. Ther. 2005, 312, 786-793. [CrossRef]

187. Franke, C.; Nöldner, M.; Abdel-Kader, R.; Johnson-Anuna, L.N.; Wood, W.G.; Müller, W.E.; Eckert, G.P. Bcl-2 upregulation and neuroprotection in guinea pig brain following chronic simvastatin treatment. Neurobiol. Dis. 2007, 25, 438-445. [CrossRef] [PubMed]

188. Bartoli, M.; Al-Shabrawey, M.; Labazi, M.; Behzadian, M.A.; Istanboli, M.; El-Remessy, A.B.; Caldwell, R.W.; Marcus, D.M.; Caldwell, R.B. HMG-CoA reductase inhibitors (statin) prevents retinal neovascularization in a model of oxygen-induced retinopathy. Investig. Ophthalmol. Vis. Sci. 2009, 50, 4934-4940. [CrossRef]

189. Lee, M.-Y.; Kuan, Y.-H.; Chen, H.-Y.; Chen, T.-Y.; Chen, S.-T.; Huang, C.-C.; Yang, I.-P.; Hsu, Y.-S.; Wu, T.-S.; Lee, E.-J. Intravenous administration of melatonin reduces the intracerebral cellular inflammatory response following transient focal cerebral ischemia in rats. J. Pineal Res. 2007, 42, 297-309. [CrossRef]

190. Chen, T.-Y.; Lee, M.-Y.; Chen, H.-Y.; Kuo, Y.-L.; Lin, S.-C.; Wu, T.-S.; Lee, E.-J. Melatonin attenuates the postischemic increase in blood-brain barrier permeability and decreases hemorrhagic transformation of tissue-plasminogen activator therapy following ischemic stroke in mice. J. Pineal Res. 2006, 40, 242-250. [CrossRef]

191. Kondoh, T.; Uneyama, H.; Nishino, H.; Torii, K. Melatonin reduces cerebral edema formation caused by transient forebrain ischemia in rats. Life Sci. 2002, 72, 583-590. [CrossRef]

192. Watson, N.; Diamandis, T.; Gonzales-Portillo, C.; Reyes, S.; Borlongan, C.V. Melatonin as an Antioxidant for Stroke Neuroprotection. Cell Transplant. 2016, 25, 883-891. [CrossRef] [PubMed]

193. Alghamdi, B.S. The neuroprotective role of melatonin in neurological disorders. J. Neurosci. Res. 2018, 96, 1136-1149. [CrossRef] [PubMed]

194. Alonso-Alconada, D.; Álvarez, A.; Arteaga, O.; Martínez-Ibargüen, A.; Hilario, E. Neuroprotective Effect of Melatonin: A Novel Therapy against Perinatal Hypoxia-Ischemia. Int. J. Mol. Sci. 2013, 14, 9379-9395. [CrossRef]

195. Tomás-Zapico, C.; Coto-Montes, A.; Tomás-Zapico, C.; Coto-Montes, A.; Tomás-Zapico, C.; Coto-Montes, A. A proposed mechanism to explain the stimulatory effect of melatonin on antioxidative enzymes. J. Pineal Res. 2005, 39, 99-104. [CrossRef]

196. Kaur, C.; Sivakumar, V.; Robinson, R.; Foulds, W.S.; Luu, C.D.; Ling, E.A. Neuroprotective effect of melatonin against hypoxia-induced retinal ganglion cell death in neonatal rats. J. Pineal Res. 2013, 54, 190-206. [CrossRef] [PubMed]

197. Xu, Y.; Lu, X.; Hu, Y.; Yang, B.; Tsui, C.-K.; Yu, S.; Lu, L.; Liang, X. Melatonin attenuated retinal neovascularization and neuroglial dysfunction by inhibition of HIF-1 $\alpha$-VEGF pathway in oxygen-induced retinopathy mice. J. Pineal Res. 2018, 64, e12473. [CrossRef] [PubMed]

198. Simonyi, A. The neuroprotective effects of apocynin. Front. Biosci. 2012, 4, 2183. [CrossRef] 
199. Jackman, K.; Miller, A.; De Silva, T.; Crack, P.J.; Drummond, G.; Sobey, C. Reduction of cerebral infarct volume by apocynin requires pretreatment and is absent in Nox2-deficient mice. Br. J. Pharmacol. 2009, 156, 680-688. [CrossRef]

200. Chen, H.; Song, Y.S.; Chan, P.H. Inhibition of NADPH oxidase is neuroprotective after ischemia-reperfusion. Br. J. Pharmacol. 2009, 29, 1262-1272. [CrossRef]

201. Kelly, K.A.; Li, X.; Tan, Z.; Vangilder, R.L.; Rosen, C.L.; Huber, J.D. NOX2 inhibition with apocynin worsens stroke outcome in aged rats. Brain Res. 2009, 1292, 165-172. [CrossRef]

202. Impellizzeri, D.; Mazzon, E.; Esposito, E.; Paterniti, I.; Bramanti, P.; Cuzzocrea, S. Effect of Apocynin, an inhibitor of NADPH oxidase, in the inflammatory process induced by an experimental model of spinal cord injury. Free Radic. Res. 2011, 45, 221-236. [CrossRef] [PubMed]

203. Rodriguez-Pallares, J.; Parga, J.A.; Muñoz, A.; Rey, P.; Guerra, M.J.; Labandeira-Garcia, J.L. Mechanism of 6-hydroxydopamine neurotoxicity: The role of NADPH oxidase and microglial activation in 6-hydroxydopamine-induced degeneration of dopaminergic neurons. J. Neurochem. 2007, 103, 145-156. [CrossRef] [PubMed]

204. Rey, P.; Lopez-Real, A.; Sánchez-Iglesias, S.; Muñoz, A.; Soto-Otero, R.; Labandeira-Garcia, J. Angiotensin type-1-receptor antagonists reduce 6-hydroxydopamine toxicity for dopaminergic neurons. Neurobiol. Aging 2007, 28, 555-567. [CrossRef] [PubMed]

205. Al-Shabrawey, M.; Bartoli, M.; El-Remessy, A.B.; Platt, D.H.; Matragoon, S.; Behzadian, M.A.; Caldwell, R.W.; Caldwell, R.B. Inhibition of NAD(P)H Oxidase Activity Blocks Vascular Endothelial Growth Factor Overexpression and Neovascularization during Ischemic Retinopathy. Am. J. Pathol. 2005, 167, 599-607. [CrossRef]

206. Saito, Y.; Uppal, A.; Byfield, G.; Budd, S.; Hartnett, M.E. Activated NAD(P)H Oxidase from Supplemental Oxygen Induces Neovascularization Independent of VEGF in Retinopathy of Prematurity Model. Investig. Opthalmol. Vis. Sci. 2008, 49, 1591-1598. [CrossRef] [PubMed]

207. Johnston, P.G.; Gillam-Krakauer, M.; Fuller, M.P.; Reese, J. Evidence-Based Use of Indomethacin and Ibuprofen in the Neonatal Intensive Care Unit. Clin. Perinatol. 2012, 39, 111-136. [CrossRef]

208. Parikh, P.; Juul, S.E. Neuroprotective Strategies in Neonatal Brain Injury. J. Pediatr. 2018, 192, $22-32$. [CrossRef]

209. Tutak, E.; Satar, M.; Zorludemir, S.; Erdogan, S.; Yapıcıoğlu, H.; Narlı, N. Neuroprotective Effects of Indomethacin and Aminoguanidine in the Newborn Rats with Hypoxic-Ischemic Cerebral Injury. Neurochem. Res. 2005, 30, 937-942. [CrossRef]

210. Lambat, Z.; Conrad, N.; Anoopkumar-Dukie, S.; Walker, R.B.; Daya, S. An Investigation into the Neuroprotective Properties of Ibuprofen. Metab. Brain Dis. 2000, 15, 249-256. [CrossRef]

211. Iwata, Y.; Nicole, O.; Zurakowski, D.; Okamura, T.; Jonas, R.A. Ibuprofen for neuroprotection after cerebral ischemia. J. Thorac. Cardiovasc. Surg. 2010, 139, 489-493. [CrossRef]

212. Świątkiewicz, M.; Zaremba, M.; Joniec, I.; Członkowski, A.; Kurkowska-Jastrzębska, I. Potential neuroprotective effect of ibuprofen, insights from the mice model of Parkinson's disease. Pharmacol. Rep. 2013, 65, 1227-1236. [CrossRef]

213. Nandgaonkar, B.N.; Rotschild, T.; Yu, K.; Higgins, R.D. Indomethacin Improves Oxygen-Induced Retinopathy in the Mouse. Pediatr. Res. 1999, 46, 184-188. [CrossRef] [PubMed]

214. Sharma, J.; Barr, S.M.; Geng, Y.; Yun, Y.; Higgins, R.D. Ibuprofen improves oxygen-induced retinopathy in a mouse model. Curr. Eye Res. 2003, 27, 309-314. [CrossRef] [PubMed]

215. Solaroglu, I. Neuroprotective Effect of Granulocyte-Colony Stimulating Factor. Front. Biosci. 2007, $12,712$. [CrossRef]

216. Schäbitz, W.-R.; Kollmar, R.; Schwaninger, M.; Juettler, E.; Bardutzky, J.; Schölzke, M.N.; Sommer, C.; Schwab, S. Neuroprotective Effect of Granulocyte Colony-Stimulating Factor After Focal Cerebral Ischemia. Stroke 2003, 34, 745-751.

217. Komine-Kobayashi, M.; Zhang, N.; Liu, M.; Tanaka, R.; Hara, H.; Osaka, A.; Mochizuki, H.; Mizuno, Y.; Urabe, T. Neuroprotective effect of recombinant human granulocyte colony-stimulating factor in transient focal ischemia of mice. J. Cereb. Blood Flow Metab. 2006, 26, 402-413. [CrossRef] [PubMed]

218. Meuer, K.; Pitzer, C.; Teismann, P.; Krüger, C.; Göricke, B.; Laage, R.; Lingor, P.; Peters, K.; Schlachetzki, J.C.; Kobayashi, K. Granulocyte-colony stimulating factor is neuroprotective in a model of Parkinson's disease. J. Neurochem. 2006, 97, 675-686. [CrossRef] [PubMed] 
219. Yanqing, Z.; Yu-Min, L.; Jian, Q.; Bao-Guo, X.; Chuan-Zhen, L. Fibronectin and neuroprotective effect of granulocyte colony-stimulating factor in focal cerebral ischemia. Brain Res. 2006, 1098, 161-169. [CrossRef]

220. Hartung, T. Anti-inflammatory effects of granulocyte colony-stimulating factor. Curr. Opin. Hematol. 1998, 5, 221-225. [CrossRef]

221. Kojima, H.; Otani, A.; Oishi, A.; Makiyama, Y.; Nakagawa, S.; Yoshimura, N. Granulocyte colony-stimulating factor attenuates oxidative stress-induced apoptosis in vascular endothelial cells and exhibits functional and morphologic protective effect in oxygen-induced retinopathy. Blood 2011, 117, 1091-1100. [CrossRef]

222. Wilkinson-Berka, J.L.; Tan, G.; Binger, K.J.; Sutton, L.; McMaster, K.; Deliyanti, D.; Perera, G.; Campbell, D.J.; Miller, A.G.; Wilkinson-Berka, J.; et al. Aliskiren reduces vascular pathology in diabetic retinopathy and oxygen-induced retinopathy in the transgenic (mRen-2)27 rat. Diabetologia 2011, 54, 2724-2735. [CrossRef] [PubMed]

223. Downie, L.E.; Pianta, M.J.; Vingrys, A.J.; Wilkinson-Berka, J.L.; Fletcher, E.L.; Wilkinson-Berka, J.L.; Wilkinson-Berka, J.L. AT1 receptor inhibition prevents astrocyte degeneration and restores vascular growth in oxygen-induced retinopathy. Glia 2008, 56, 1076-1090. [CrossRef] [PubMed]

224. Downie, L.E.; Hatzopoulos, K.M.; Pianta, M.J.; Vingrys, A.J.; Wilkinson-Berka, J.L.; Kalloniatis, M.; Fletcher, E.L.; Wilkinson-Berka, J.L.; Wilkinson-Berka, J.L. Angiotensin type-1 receptor inhibition is neuroprotective to amacrine cells in a rat model of retinopathy of prematurity. J. Comp. Neurol. 2010, 518, 41-63. [CrossRef] [PubMed]

225. Biehl, J.K.; Russell, B. Introduction to stem cell therapy. J. Cardiovasc. Nurs. 2009, 24, 98-103. [CrossRef] [PubMed]

226. Lai, A.; Fu, Z.; Lo, A. Stem cell therapy for retinopathy of prematurity. Anat. Physiol. 2013. [CrossRef]

227. Machalińska, A.; Modrzejewska, M.; Kotowski, M.; Dziedziejko, V.; Kucia, M.; Kawa, M.; Safranow, K.; Baśkiewicz-Masiuk, M.; Modrzejewska, A.; Karczewicz, D. Circulating stem cell populations in preterm infants: Implications for the development of retinopathy of prematurity. Arch. Ophthalmol. 2010, 128, 1311-1319. [CrossRef] [PubMed]

228. Paczkowska, E.; Kucia, M.; Koziarska, D.; Halasa, M.; Safranow, K.; Masiuk, M.; Karbicka, A.; Nowik, M.; Nowacki, P.; Ratajczak, M.Z.; et al. Clinical Evidence That Very Small Embryonic-Like Stem Cells Are Mobilized into Peripheral Blood in Patients After Stroke. Stroke 2009, 40, 1237-1244. [CrossRef]

229. Ratajczak, M.; Machalinski, B.; Wojakowski, W.; Ratajczak, J.; Kucia, M. A hypothesis for an embryonic origin of pluripotent Oct-4+ stem cells in adult bone marrow and other tissues. Leukemia 2007, 21, 860. [CrossRef]

230. Ritter, M.R.; Banin, E.; Moreno, S.K.; Aguilar, E.; Dorrell, M.I.; Friedlander, M. Myeloid progenitors differentiate into microglia and promote vascular repair in a model of ischemic retinopathy. J. Clin. Investig. 2006, 116, 3266-3276. [CrossRef]

231. Medina, R.J.; O’Neill, C.L.; Humphreys, M.W.; Gardiner, T.A.; Stitt, A.W. Outgrowth Endothelial Cells: Characterization and Their Potential for Reversing Ischemic Retinopathy. Investig. Opthalmol. Vis. Sci. 2010, 51, 5906-5913. [CrossRef]

232. Noueihed, B.; Rivera, J.C.; Chemtob, S. AB028. Mesenchymal stem cells repair retinal vascular damage in retinopathy of prematurity mouse model. Ann. Eye Sci. 2018, 3, AB028. [CrossRef]

233. Moisseiev, E.; Anderson, J.D.; Oltjen, S.; Goswami, M.; Zawadzki, R.J.; Nolta, J.A.; Park, S.S. Protective Effect of Intravitreal Administration of Exosomes Derived from Mesenchymal Stem Cells on Retinal Ischemia. Curr. Eye Res. 2017, 42, 1358-1367. [CrossRef] [PubMed]

234. Ma, Q.; Liu, F.; Shi, M.; Sun, C.; Tan, Z.; Chang, X.; Li, Q.; Feng, Z. Bone marrow mesenchymal stem cells modified by angiogenin-1 promotes tissue repair in mice with oxygen-induced retinopathy of prematurity by promoting retinal stem cell proliferation and differentiation. J. Cell. Physiol. 2019, 234, 21027-21038. [CrossRef] [PubMed]

235. Mendel, T.A.; Clabough, E.B.D.; Kao, D.S.; Demidova-Rice, T.N.; Durham, J.T.; Zotter, B.C.; Seaman, S.A.; Cronk, S.M.; Rakoczy, E.P.; Katz, A.J.; et al. Correction: Pericytes Derived from Adipose-Derived Stem Cells Protect against Retinal Vasculopathy. PLoS ONE 2013, 8, 65691. [CrossRef]

236. Dogra, M.R.; Katoch, D. An Update on Retinopathy of Prematurity (ROP). Indian J. Pediatr. 2017, 84, $930-936$. [CrossRef] [PubMed]

237. Broxterman, E.C.; Hug, D.A. Retinopathy of Prematurity: A Review of Current Screening Guidelines and Treatment Options. Mo. Med. 2016, 113, 187-190. [PubMed] 
238. Cryotherapy for Retinopathy of Prematurity Cooperative Group. Multicenter trial of cryotherapy for retinopathy of prematurity: Preliminary results. Pediatrics 1988, 81, 697-706.

239. Elsas, F.; Collins, M.; Jones, J.; Kimble, J.; Kline, L.; Witherspoon, D.; Roth, A.; Demorest, B.; Gilbert, W.; Plotsky, D. Multicenter trial of cryotherapy for retinopathy of prematurity: Ophthalmological outcomes at 10 years. Arch. Ophthalmol. 2001, 119, 1110-1118.

240. Palmer, E.; Hardy, R.; Dobson, V.; Phelps, D.; Quinn, G.; Summers, C.; Krom, C.; Tung, B. 15-year outcomes following threshold retinopathy of prematurity: Final results from the multicenter trial of cryotherapy for retinopathy of prematurity. Arch. Ophthalmol. 2005, 123, 311-318. [PubMed]

241. Clark, D.; Mandal, K. Treatment of retinopathy of prematurity. Early Hum. Dev. 2008, 84, 95-99. [CrossRef] [PubMed]

(C) 2019 by the authors. Licensee MDPI, Basel, Switzerland. This article is an open access article distributed under the terms and conditions of the Creative Commons Attribution (CC BY) license (http://creativecommons.org/licenses/by/4.0/). 